ANL-AFP-11

ANL-AFP-11

\title{
EQUATION OF STATE AND TRANSPORT \\ PROPERTIES OF URANIUM AND PLUTONIUM CARBIDES \\ IN THE LIQUID REGION
}

by

A. Sheth and L. Leibowitz

Chemical Engineering Division

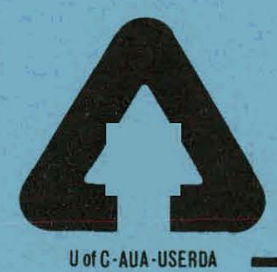

ARGONNE NATIONAL LABORATORY, ARGONNE, ILLINOIS

Prepared for the U. S. ENERGY RESEARCH

AND DEVELOPMENT ADMINISTRATION under Contract W-31-109-Eng-38 


\section{DISCLAIMER}

This report was prepared as an account of work sponsored by an agency of the United States Government. Neither the United States Government nor any agency Thereof, nor any of their employees, makes any warranty, express or implied, or assumes any legal liability or responsibility for the accuracy, completeness, or usefulness of any information, apparatus, product, or process disclosed, or represents that its use would not infringe privately owned rights. Reference herein to any specific commercial product, process, or service by trade name, trademark, manufacturer, or otherwise does not necessarily constitute or imply its endorsement, recommendation, or favoring by the United States Government or any agency thereof. The views and opinions of authors expressed herein do not necessarily state or reflect those of the United States Government or any agency thereof. 


\section{DISCLAIMER}

Portions of this document may be illegible in electronic image products. Images are produced from the best available original document. 
The facilities of Argonne National Laboratory are owned by the United States Government. Under the terms of a contract (W-31-109-Eng-38) between the U. S. Energy Research and Development Administration, Argonne Universities Association and The University of Chicago, the University employs the staff and operates the Laboratory in accordance with policies and programs formulated, approved and reviewed by the Association.

\section{MEMBERS OF ARGONNE UNIVERSITIES ASSOCIATION}

The University of Arizona Carnegie-Mellon University Case Western Reserve University The University of Chicago University of Cincinnati Illinois Institute of Technology University of Illinois Indiana University Iowa State University The University of Iowa
Kansas State University The University of Kansas Loyola University Marquette University Michigan State University The University of Michigan University of Minnesota University of Missouri Northwestern University University of Notre Dame
The Ohio State University

Ohio University

The Pennsylvania State University

Purdue University

Saint Louis University

Southern Illinois University

The University of Texas at Austin Washington University Wayne State University The University of Wisconsin

\section{NOTICE}

This report was prepared as an account of work sponsored by the United States Government. Neither the United States nor the United States Energy Research and Development Administration, nor any of their employees, nor any of their contractors, subcontractors, or their employees, makes any warranty, express or implied, or assumes any legal liability or responsibility for the accuracy, completeness or usefulness of any information, apparatus, product or process disclosed, or represents that its use would not infringe privately-owned rights. Mention of commercial products, their manufacturers, or their suppliers in this publication does not imply or connote approval or disapproval of the product by Argonne National Laboratory or the U. S. Energy Research and Development Administration. 
Argonne National Laboratory 9700 South Cass Avenue Argonne, Illino is 60439
Distribution Category: LMFBR Fuels and Materials Engineering and Development (UC-79b)

EQUATION OF STATE AND TRANSPORT

PROPERTIES OF URANIUM AND PLUTONIUM CARBIDES

IN THE LIQUID REGION

by

A. Sheth and L. Leibowitz

Chemical Engineering Division

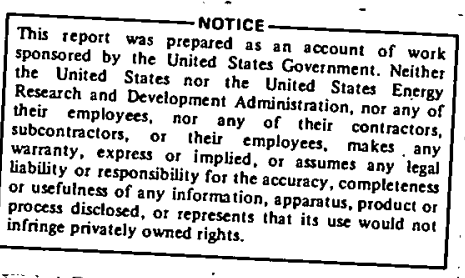
sponsored by the United as an account of work the United States nor the Unovernment. Neither their subcontractors, nor any of their contractors, warranty, express or implied, or assumes any any or usefulnes of any infor the accuracy, completenes process disclosed, or represents that its use would not

September 1975 
THIS PAGE

\section{WAS INTENTIONALLY LEFT BLANK}


TABLE OF CONTENTS

Page

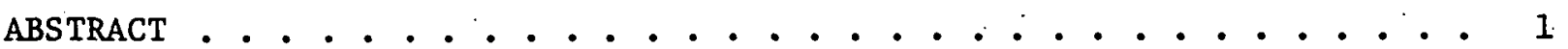

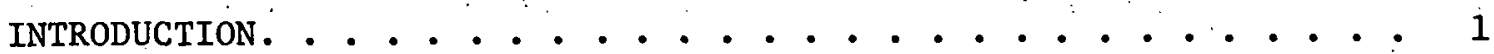

Density of Carbide Fuels . . . . . . . . . . . . • . . . 2

Heat Capacity and Enthalpy of Carbide Fuels. . . . . . . . 4

Vapor Pressure of Carbide Fuels. . . . . . . . . . . . . 11

Thermal Conductivity of Carbide Fuels. . . . . . . . . . . 23

Viscosity of Carbide Fuels . . . . . . . . . . . . . . 24

Emissivity of Carbide Fuels. . . . . . . . . . . . . . 27

Conclusions. . . . . . . . . . . . . . . . . . . . . 29

ACKNOWLEDGMENTS . . . . . . . . . . . . . . . . . . 30

REFERENCES . . . . . . . . . . . . . . . . . . . . . 31 


\section{LIST OF FIGURES}

No. Title

$\underline{\text { Page }}$

1. Phase Diagram of the Pu-C System . . . . . . . . . . 21

2. Total Normal Emittance of Refractory Carbides. . . . . . . 28

3. Normal Spectral Emittance of Refractory Carbides . . . . . . 29 
1 Recommended Values for Heat Capacity and Enthalpy of UC below the Melting Point . . . . . . . . . . 5

2 Recommended Values for Heat Capacity and Enthalpy of $\mathrm{PuC}_{0.88}$ below the Melting Point. . . . . . . . . 6

3 Recommended Values for Heat Capacity and Enthalpy of (U $0.8 \mathrm{Pu}_{0.2}$ ) C below the Melting Point............ 7

4 Values of Parameters to Calculate Heat Capacity at

Very High Temperatures. . . . . . . . . . . . 8

5 Estimated Values of Heat Capacity and Enthalpy of UC in Liquid Region . . . . . . . . . . . . . . . 9

6 Estimated Values of Heat Capacity and Enthalpy of $\mathrm{PuC}_{0.88}$ in Liquid Region. ................ 10

7 Estimated Values of Heat Capacity and Enthalpy of $\left(\mathrm{U}_{0.8} \mathrm{Pu}_{0.2}\right) \mathrm{C}$ in the Liquid Region............. 12

8. Low-Temperature Vapor Pressure Data of UC . . . . . . . . . 14

9 Estimated Vapor Pressure Data of UC . . . . . . . . 16

10 Low-Temperature Vapor Pressure Data of $\left(\mathrm{U}_{0.8} \mathrm{Pu}_{0.2}\right) \mathrm{C} . . .18$

11 Estimated Vapor Pressure Data of $\left(\mathrm{U}_{0.8} \mathrm{Pu}_{0.2}\right) \mathrm{C} \ldots$. . . . 19

12 Low-Temperature Vapor Pressure Data of $\mathrm{PuC}_{0.88}$. . . . . . 20

13 Low-Temperature Vapor Prcacurc Data of PuC 0.88 (Calculated using average values derived from $\mathrm{Pu}(l)+\mathrm{PuC}$ and $\mathrm{PuC}+\mathrm{Pu}_{2} \mathrm{C}_{3}$ phases)........................ 22

14 Estimated Vapor Pressure Data of $\mathrm{PuC}_{0.88}$. . . . . . . 23

15 Thermal Conductivity of $100 \%$ Theoretically Dense UC . . . . 25

16 Thermal Conductivity of $100 \%$ Theoretically Densy PuC. . . . 25

17 Thermal Conductivity of $100 \%$ Theoretically Dense

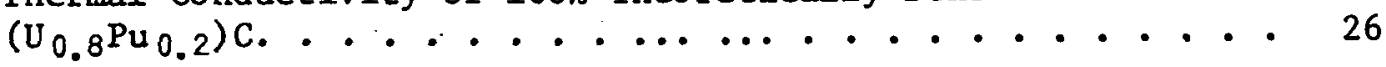

18 Thermal Conductivity of Carbide Fuels in the Liquid Region (100\% T.D.)................... 26

19 Viscosity of Carbide Fuels. . . . . . . . . . . 27 


\section{EQUATION OF STATE AND TRANSPORT \\ PROPERTIES OF URANIUM AND PLUTONIUM CARBIDES \\ IN THE LIQUID REGION}

by

A. Sheth and L. Leibowitz

ABSTRACT

By the use of available low-temperature data for various thermophysical and transport properties for uranium and plutonium carbides, values above the melting point were estimated. Sets of recommended values have been prepared for the compounds $\mathrm{UC}, \mathrm{PuC}$, and $(\mathrm{U}, \mathrm{Pu}) \mathrm{C}$. The properties that have been evaluated are density, heat capacity, enthalpy, vapor pressure, thermal conductivity, viscosity, and emissivity.

\section{INTRODUCTION}

To improve the performance of breeder reactors, fuels other than oxide fuels are being developed. The advanced fuels currently being considered are carbides and nitrides of uranium and plutonium. These fuels have better neutronic properties and higher thermal conductivities than oxide fuels. These properties will permit operation of fuel pins at higher linear power ratings and will also allow enough flexibility in design to optimize breeding ratio and minimize fabrication cost and fissile-material inventory.

Reactor safety analysis depends on the application of massive computer codes to predict the behavior of a system as a result of various hypothetical core disruptive accidents (HCDA). Involved in these calculations are many thermodynamic and transport properties of the materials employed in the reactor. These data are required for temperatures ranging from those of normal operation to as high as $6000^{\circ} \mathrm{C}$. Although adequate data are available at lower temperatures, values for the temperature region of interest to the safety analyst are sparse, and, therefore, efforts are being made to extrapolate low-temperature data to these higher temperatures. The compounds being considered are $\mathrm{UC}, \mathrm{UN}, \mathrm{PuC}, \mathrm{PuN},(\mathrm{U}, \mathrm{Pu}) \mathrm{C}$, and $(\mathrm{U}, \mathrm{Pu}) \mathrm{N}$. The properties that are being extrapolated or estimated by us are heat capacity, enthalpy, density, vapor pressure, thermal conductivity, viscosity, and emissivity. The present report describes only. the work done on carbide fuels. A separate report is being prepared on the work done on nitride fuels.

To extrapolate varfous properties into the liquid region, the lowtemperature data were selected from the recent critical evaluations made by scientists working at Argonne National Laboratory 1,2 and Los Alamos Sclentific Laboratory. 3,4 By extrapolating data from lower to higher 
TABLE 3. Recommended Values for Heat Capacity and Enthalpy of $\left(\mathrm{U}_{0.8} \mathrm{Pu}_{0.2}\right) \mathrm{C}$ below the Melting Point ${ }^{\mathrm{a}}$

\begin{tabular}{cccccc}
\hline $\begin{array}{c}\text { Temp } \\
\mathrm{K}\end{array}$ & $\begin{array}{c}\mathrm{C}_{\mathrm{P}}^{\circ} \\
\mathrm{cal} /(\mathrm{mol})\end{array}(\mathrm{K})$ & $\begin{array}{c}\mathrm{H}_{\mathrm{T}}^{\circ}-\mathrm{H}_{298}^{\circ} \\
\mathrm{cal} / \mathrm{mol}\end{array}$ & $\begin{array}{c}\text { Temp, } \\
\mathrm{K}\end{array}$ & $\begin{array}{c}\mathrm{C}_{\mathrm{P}}^{\circ} \\
\mathrm{cal} /(\mathrm{mol})(\mathrm{K})\end{array}$ & $\begin{array}{c}\mathrm{H}_{\mathrm{T}}^{\circ}-\mathrm{H}_{298}^{\circ} \\
\mathrm{cal} / \mathrm{mol}\end{array}$ \\
\hline 300 & 11.94 & 24 & 1600 & 16.02 & 18844 \\
400 & 12.93 & 1274 & 1700 & 16.29 & 20459 \\
500 & 13.44 & 2595 & 1800 & 16.56 & 22101 \\
600 & 13.78 & 3957 & $1900^{\mathrm{b}}$ & 16.85 & 23772 \\
700 & 14.03 & 5348 & $2000^{\mathrm{b}}$ & 17.15 & 25472 \\
800 & 14.26 & 6762 & $2100^{\mathrm{b}}$ & 17.46 & 27202 \\
900 & 14.46 & 8198 & $2200^{\mathrm{b}}$ & 17.79 & 28965 \\
1000 & 14.67 & 9655 & $2300^{\mathrm{b}}$ & 18.13 & 30761 \\
1100 & 14.87 & 11131 & $2400^{\mathrm{b}}$ & 18.49 & 32592 \\
1200 & 15.08 & 12629 & $2500^{\mathrm{b}}$ & 18.85 & 34459 \\
1300 & 15.30 & 14148 & $2600^{\mathrm{b}}$ & 19.23 & 36363 \\
1400 & 15.53 & 15690 & $2700^{\mathrm{b}}$ & 19.63 & 38306 \\
1500 & 15.77 & 17255 & $2758^{\mathrm{b}}$ & 19.86 & 39451 \\
\hline
\end{tabular}

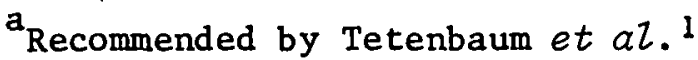

$b_{\text {Extrapolation based on: }}$

$$
\begin{aligned}
& \mathrm{H}_{\mathrm{T}}^{\circ}-\mathrm{H}_{298}^{\circ}=-4787+13.882 \mathrm{~T}+1.4283 \times 10^{-4} \mathrm{~T}^{2}+2.2886 \times 10^{-7} \mathrm{~T}^{3}+\frac{188170}{\mathrm{~T}} \\
& \mathrm{C}_{\mathrm{P}}^{\circ}=13.882+2.8565 \times 10^{-4} \mathrm{~T}+6.8597 \times 10^{-7} \mathrm{~T}^{2}-\frac{188170}{\mathrm{~T}^{2}}
\end{aligned}
$$

the solid state, one may need to apply different methods to extrapolate lowtemperature data into the liquid region. Therefore, in the absence of adequate experimental information, we have applied the thermodynamic approach recommended by Winslow, ${ }^{9}$. to both compounds for the calculation of heat capacity and enthalpy values in the 1iquid region.

following equation:

From basic thermodynamic considerations, one may derive the

$$
C_{P}=C_{\dot{v}}(1+\gamma \beta T)
$$

where

$$
C_{P}=\text { heat capacity at constant pressure }
$$


temperatures, sets of self-consistent values for the solid and liquid regions were obtained. In the few cases for which no data were available, estimates were made on the basis of similarity or various correlations between related compounds. To supplement the data that are presented in tabular form, best fitting equations were developed by applying regression techniques to standard forms of equations. No attempt was made to determine the optimum form of the equation. The estimated sets of properties values, along with the recommended low-temperature data that were used, are given below. The basis for choosing a method of extrapolation or estimation is also discussed.

Density of Carbide Fuels

The density of molten ceramic fuel is an important parameter in safety analyses. No reliable data on the density of liquid carbide fuels are available, and therefore we have made use of data on thermal expansion and density of solid carbides to derive an equation showing the temperature dependency of the density of the 1 iquid carbides. Riohardo meaourcd the thermal expansion coefficient in 1iquid UC, as well as the expansion accompanying the transition from solid to liquid. However, the chemical analyses that he performed after the experiments showed that the sample had a composition near $\mathrm{UC}_{2}$. The values reported by him may therefore by suspect. Andrew ${ }^{3}$ has recently reviewed the density and thermal expansion data of carbide fuels in the solid state. He has given values for the average linear thermal expansion coefficients for $\mathrm{UC}, \mathrm{PuC}_{0.85}$, and $\left(\mathrm{U}_{0.95} \mathrm{Pu}_{0.05}\right)_{0.98}$ as a function of temperature.

In deriving the temperature dependency of density of the liquid phase from low-temperature data, our approach was as follows: Andrew ${ }^{3}$ has given values for the average linear thermal expansion coefficient for UC solid from room temperature to $2000^{\circ} \mathrm{C}$. Extrapolating his data to the recommended melting point of UC of $2780 \mathrm{~K}$ (recommended by Fee and Johnson ${ }^{2}$ ), we obtained the average linear thermal expansion coefficient for the solid, $\alpha$, from room temperature to the melting point; $a_{s}$ was found to be equal to $1.30^{\circ} \times 10^{-5} / \mathrm{K}$. In the absence of a reliable value for the volume change on melting $\left(\Delta \mathrm{V} / \mathrm{V}_{\mathrm{s}}\right)$ for UC, we took the value of $26.06 \%$, which is the value recommended for $\mathrm{NaC1}$ by Kirshenbaum et al. ${ }^{6}$ From the data on $\mathrm{NaCl}$ given by $\mathrm{Janz}, 7$ the ratio of linear thermal expansion coefficients for the solid and liquid states of $\mathrm{NaCl}$ was calculated to be 0.5 . By using this ratio and the value. of $\alpha_{s}$ given earlier, the average value for the thermal expansion coefficient of liquid UC $\left(\alpha_{\ell}\right)$ from the melting point to a higher temperature, $T$, was estimated as being equal to $2.60 \times 10^{-5} / \mathrm{K}$. By using a value for the density of colld UC at $20^{\circ} \mathrm{C}$ of $13.61 \mathrm{~g} / \mathrm{cm}^{3}$ (recommended by Andrew ${ }^{3}$ ), the following equation was derived to give the density of liquid UC:

$$
\rho_{L}=\frac{13: 61}{1.2606\left[1+3\left(T_{m}-293\right) \alpha_{s}\right]\left[1+3\left(T-T_{m}\right) \alpha_{\ell}\right]} \quad T \geqslant T_{m}
$$

where $\rho_{\mathrm{L}}=1$ iquid density, $\mathrm{g} / \mathrm{cm}^{3}$ 


$$
\begin{aligned}
& T_{\mathrm{m}}=\text { melting point, } \mathrm{K} \\
& \alpha_{\mathrm{s}}=\begin{array}{l}
\text { average linear thermal expansion coefficient for solid, } \\
\mathrm{cm} \mathrm{cm}^{-1} \mathrm{~K}^{-1}
\end{array} \\
& \alpha_{\ell}=\begin{array}{l}
\text { average linear thermal expansion coefficient in liquid, } \\
\mathrm{cm} \mathrm{cm}^{-1} \mathrm{~K}^{-1}
\end{array} \\
& \mathrm{~T}=\text { temperature, } \mathrm{K}
\end{aligned}
$$

Substitution of the values for $\alpha_{s}, T_{m}$, and $\alpha_{l}$ for UC and a further simplification reduced the above equation to

$$
\rho_{\mathrm{L}}[\mathrm{UC}]=\frac{12.57}{1+9.98 \times 10^{-5} \mathrm{~T}} \quad \mathrm{~T} \geqslant \mathrm{~T}_{\mathrm{m}}
$$

Equation 2 represents our best estimate of the density of liquid UC, but it should be used cautiously to calculate liquid density at temperatures much higher than the melting point. The value for $\alpha_{\ell}$ may change with temperature, and the method of calculation, $i . e$. by analogy with $\mathrm{NaCl}$, may not be valid at higher temperatures; moreover, in real situations, the chemical composition of UC may change, giving rise to unknown effects on density.

The low-temperature data for $\mathrm{PuC}_{0.85}$ recommended by Andrew ${ }^{3}$ was used to estimate a value of $\alpha_{s}$ for $\mathrm{PuC}_{0.88^{\circ}}$ In this estimate, the effect of stoichiometry was neglected. Between room temperature and the melting point of PuC of $1875 \mathrm{~K}$ (recommended by Fee and Johnson ${ }^{2}$ ), the value of $\alpha_{s}$ was estimated to be $1.13 \times 10^{-5} / \mathrm{K}$. In the absence of information on the volume expansion on melting and the liquid thermal expansion coefficient, the same approach used for UC was adopted here. The value for $\alpha_{\text {f }}$ was calculated to be $2.26 \times 10^{-5} / \mathrm{K}$ and the percentage volume increase on melting was assumed to be equal to $26.06 \%$. By using the recommended room-temperature density of $13.55 \mathrm{~g} / \mathrm{cm}^{3}$ for $P_{0.9} 0$ and the above values of $\alpha_{s}, T_{m}$, and $\alpha_{\ell}$, the following equation was derived for the liquid density of PuC 0.88 :

$$
\rho_{L}\left[\mathrm{PuC}_{0.88}\right]=\frac{11.69}{1+7.77 \times 10^{-5 \cdot T}} \quad \mathrm{~T} \geqslant \mathrm{~T}_{\mathrm{m}}
$$

According to Andrew, 3 the effect of stoichiometry, the slight addition (0.1 wt \%) of $\mathrm{Ni}$, and a small amount of the sesquicarbide phase do not change the thermal expansion coefficients of (U, $\mathrm{Pu}) \mathrm{C}$ within the experimental error of $5 \%$. On this basis, $\alpha_{s}$ for $\left(U_{0.8} \mathrm{Pu}_{0.2}\right) \mathrm{C}$ from room temperature to the melting point of $2758 \mathrm{~K}$ (recommended by $\overrightarrow{F e e}$ and Johnson ${ }^{2}$ ) was estimated from the low-temperature data for $\left(\mathrm{U}_{0.95} \mathrm{Pu}_{0.05}\right) \mathrm{C}_{0.98}$ given by Andrew. ${ }^{3}$ This value is equal to $1.29 \times 10^{-5} / \mathrm{K}$. For $\alpha_{l}$ and the percentage increase in volume on melting, the same assumptions made as those for $\mathrm{UC}$ and $\mathrm{PuC}_{0.88}$. By using a value for the room temperature density of $\left(\mathrm{U}_{0.8} \mathrm{Pu}_{0.2}\right) \mathrm{C}_{0.95}$ of $13.45 \mathrm{~g} / \mathrm{cm}^{3}$, as recommended by Andrew, ${ }^{3}$ and the values of $\alpha_{s}, T_{m}$, and $\alpha_{l}$, the following equation was derived for the liquid density of $\left(\mathrm{U}_{0.8} \mathrm{Pu}_{0.2}\right) \mathrm{C}$ :

$$
\rho_{\mathrm{L}}\left[\left(\mathrm{U}_{0.8} \mathrm{Pu}_{0.2}\right) \mathrm{C}\right]=\frac{12.39}{1+9.84 \times 10^{-5} \mathrm{~T}} \quad \mathrm{~T}>\mathrm{T}_{\mathrm{m}}
$$


In using Eqs. 3 and 4 for temperatures much above the melting point, the same cautionary statements apply as those made above for Eq. 2 .

Heat Capacity and Enthalpy of Carbide Fuels

The low-temperature data for $\mathrm{UC}, \mathrm{PuC}_{0,88}$, and $\left(\mathrm{U}_{0,8} \mathrm{Pu}_{0,2}\right) \mathrm{C}$ were taken from the report by Tetenbaum et $a l^{1}{ }^{1}$ for the purpose of extrapolating into the liquid region. The data used were reported up to temperatures near the melting points recommended by Fee and Johnson. ${ }^{2}$. In Tables $1-3$, the heat capacity and enthalpy values for the three carbides are given up to the recommended melting points.

By using an ideal solution approach and the recommended 1,8 heat capacity data for $\mathrm{UC}$ and $\mathrm{PuC}_{0.88}$, the heat capacity of $\left(\mathrm{U}_{0.8} \mathrm{Pu}_{0.2}\right) \mathrm{C}$ could be estimated. The resulting values would show a very steep increase in $\mathrm{C}_{\mathrm{p}}^{\circ}$ with increasing temperature. Th1s behavior would be similar to that of $\mathrm{PuC}_{0.88}$, probably resulting from substoichiometry and vacancy formation. However, since (U $0.8 \mathrm{Pu}_{0,2}$ ) $\mathrm{C}$ is a stoichiometric material one would expect it to behave much like UC where $C_{p}^{0}$ values did not show very steep rise with increasing temperature. Simply using the $\mathrm{PuC}_{0.88}$ data, we believe, would give unrealisticly high values. As an alternative approach, the following assumptions were made to calculate $\mathrm{C}_{\mathrm{p}}^{\circ}$ for the mixed carbide in solid state:

(1) From $\mathrm{T}=300$ to $1000 \mathrm{~K}$, $\left(\mathrm{U}_{0.8} \mathrm{Pu}_{0.2}\right) \mathrm{C}($ solid $)=\mathrm{UC}($ solid $)+\mathrm{PuC}_{0.88}$ (solid)

The calculations were made using the $C_{p}^{\circ}$ data of the IAEA panel for both $\mathrm{UC}(\mathrm{s})$ and $\mathrm{PuC}_{0.88}$ (s).

(2) From $\mathrm{T}=1900$ to $2700 \mathrm{~K}$, $\left(\mathrm{U}_{0.8} \mathrm{Pu}_{0.2}\right) \mathrm{C}($ solid $)=\mathrm{UC}($ solid $)+\mathrm{PuC}_{0.88}$ (1iquid)

The calculations were made using the $C_{p}^{\circ}$ data of the IAEA panel for UC $(s)$. $\mathrm{C}_{\mathrm{p}}^{\circ}$ values for $\mathrm{PuC}_{0.88}(l)$ were calculated by a method due to Winslow $9,1 \delta$ (described in detail below).

The resulting heat capacity values for the stoichiometric mixed carbide in the range from $1900-2700 \mathrm{~K}$ were in a good agreement with the UC values in the same range. Because of this agreement, data calculated from the IAEA panel's recommended values for $\mathrm{UC}$ and $\mathrm{PuC}_{0.88}$ in the range from 300 to $1000 \mathrm{~K}$ were connected by a smooth curve to the values in the $1900-2700 \mathrm{~K}$ region and a least-squares $f i t$ was made. The $C_{p}^{\circ}$ values calculated from the resulting equation did not show the steep rise with increasing temperature. The enthalpy values were then calculated from the fitted equation. The values calculated from these derived equations and the equations themselves are given in Table 3.

To extrapolate the low-temperature enthalpy data into the liquid region, a correction has to be made for the heat of fusion at the melting point. Based on the different behavior of $\mathrm{C}_{\mathrm{p}}^{\circ}$ data for $\mathrm{UC}$ and $\mathrm{PuC}_{0.88}$ noted above for 
TABLE 1. Recomended Values for Heat Capacity and Enthalpy of UC below the Melting Point ${ }^{a}$

\begin{tabular}{|c|c|c|}
\hline $\begin{array}{l}\text { Temp, } \\
\mathrm{K}\end{array}$ & $\begin{array}{c}\mathrm{C}_{\mathrm{p}}^{0} \\
\mathrm{cal} /(\mathrm{mol})(\mathrm{K})\end{array}$ & $\begin{array}{l}\mathrm{H}_{\mathrm{T}}^{0}-\mathrm{H}_{298}^{\circ}, \\
\mathrm{cal} / \mathrm{mol} \\
\end{array}$ \\
\hline 300 & 12.01 & 22 \\
\hline 400 & 13.19 & 1290 \\
\hline 500 & 13.76 & 2640 \\
\hline 600 & 14.10 & 4034 \\
\hline 700 & 14.36 & 5458 \\
\hline 800 & 14.57 & 69.04 \\
\hline 900 & 14.76 & 8371 \\
\hline 1000 & 14.95 & 9857. \\
\hline 1100 & 15.15 & 11362 \\
\hline 1200 & 15.36 & 12887 \\
\hline 1300 & 15.58 & 14434 \\
\hline 1400 & 15.82 & 16004 \\
\hline 1500 & 16.07 & 17598 \\
\hline 1600 & 16.34 & 19218 \\
\hline 1700 & 16.62 & 20865 \\
\hline 1800 & 16.93 & 22543 \\
\hline 1900 & 17.25 & 24252 \\
\hline 2000 & 17.59 & 25994 \\
\hline 2100 & 17.96 & 27771 \\
\hline 2200 & 18.34 & 29586 \\
\hline 2300 & 18.74 & 31439 \\
\hline 2400 & 19.16 & 33334 \\
\hline $2500^{D}$ & 19.60 & 35272 \\
\hline $2600^{b}$ & 20.06 & 37254 \\
\hline $2700^{b}$ & 20.53 & 39283 \\
\hline $2780^{b}$ & 20.93 & 40941 \\
\hline
\end{tabular}

${ }^{a}$ Recommended data of Tetenbaum et al.1

$\mathrm{b}_{\text {Extrapolation based on: }}$

$$
\begin{aligned}
\mathrm{H}_{\mathrm{T}}^{\circ}-\mathrm{H}_{298}^{\circ}= & 5.174 \times 10^{3}+14.727 \mathrm{~T}-2.6733 \times 10^{-4} \mathrm{~T}^{2}+3.3304 \times 10^{-7} \mathrm{~T}^{3} \\
& +\frac{2.3797 \times 10^{-6}}{\mathrm{~T}} \quad(300=2418 \mathrm{~K}) \\
\mathrm{C}_{\mathrm{P}}^{\circ}=14.727-5.3466 \times 10^{-4} \mathrm{~T} & +9.9912 \times 10^{-7} \mathrm{~T}^{2}-\frac{2.3797 \times 10^{5}}{\mathrm{~T}^{2}}
\end{aligned}
$$


TABLE 2. Recommended Values for Heat Capacity and Enthalpy
of $\mathrm{PuC}_{0.88}$ below the Melting Point

\begin{tabular}{|c|c|c|}
\hline $\begin{array}{c}\text { Temp } \\
\mathrm{K} \\
\end{array}$ & $\begin{array}{c}\mathrm{C}_{\mathrm{p}}^{\circ} \\
\mathrm{cal} /(\mathrm{mol})(\mathrm{K}) \\
\end{array}$ & $\begin{array}{l}\mathrm{H}_{\mathrm{T}}^{\circ}-\mathrm{H}_{298}^{\circ} \\
\mathrm{cal} / \mathrm{mol} \\
\end{array}$ \\
\hline 300 & 11.42 & 21 \\
\hline 400 & 11.86 & 1192 \\
\hline 500 & 11.93 & 2382 \\
\hline 600 & 12.02 & 3578 \\
\hline 700 & 12.26 & 4790 \\
\hline 800 & 12.74 & 6039 \\
\hline 900 & 13.48 & 7349 \\
\hline 1000 & $14.51^{\circ}$ & 8746 \\
\hline 1100 & 15.80 & 10259 \\
\hline 1200 & 17.38 & 11915 \\
\hline 1300 & 19.24 & 13744 \\
\hline 1400 & 21.42 & 1577.5 \\
\hline 1500 & 23.85 & 18036 \\
\hline $1600^{b}$ & 26.60 & 20557 \\
\hline $1700^{\mathrm{b}}$ & 29.66 & 23367 \\
\hline $1800^{b}$ & 32.98 & 26496 \\
\hline $1875^{b}$ & 35.68 & 29070 \\
\hline
\end{tabular}

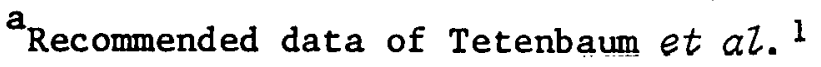

$b_{\text {Extrapolation baeed on }}$

$$
\begin{aligned}
\mathrm{H}_{\mathrm{T}}^{\circ}-\mathrm{H}_{298}^{\circ}= & -5728.5+18.607 \mathrm{~T}-9.3415 \times 10^{-3} \mathrm{~T}^{2}+4.9473 \times 10^{-6} \mathrm{~T}^{3} \\
& +\frac{2.6291 \times 10^{5}}{\mathrm{~T}} \\
\mathrm{C}_{\mathrm{P}}^{\circ}= & 18.607-1.8683 \times 10^{-2} \mathrm{~T}+1.4842 \times 10^{-5} \mathrm{~T}^{2}-\frac{2.6291 \times 10^{5}}{\mathrm{~T}^{2}} .
\end{aligned}
$$




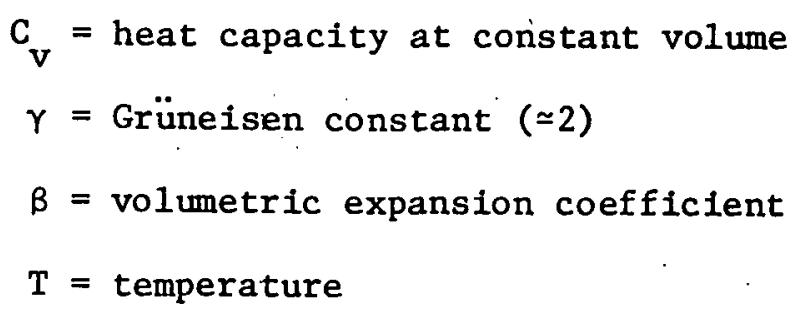

Although Winslow 10 has given the relationship between $\beta$ and other lattice parameters for some compounds, information on the carbide fuels was not given. Hence, we decided to use the values listed in Table 4. Values of the Grüneisen constant for most materials lie between $I$ and 3 . We have therefore taken $\gamma=2$. For $C_{V}$ a value of $3 R$ per atom was used as wae donc by Winslow ${ }^{9}$. From the earlier section on density, values of $\alpha_{l}$ were used to calculate $\beta$ assuming a simple relation of volumetric expansion coefficicnt being three times greater than linear expansion coefficient.

TABLE 4. Values of Parameters to Calculate Heat Capacity at Very High Temperatures

\begin{tabular}{cccc}
\hline Parameter & UC & $\mathrm{PuC}_{0.88}$ & $\mathrm{U}_{0.8} \mathrm{Pu}_{0.2}$ ) C \\
\hline$\gamma$ & 2 & 2 & 2 \\
$\beta$ & $7.81 \times 10^{-5}$ & $6.78 \times 10^{-5}$ & $7.74 \times 10^{-5}$ \\
$\mathrm{C}_{\mathrm{v}}^{\mathrm{a}}$ & $6 \mathrm{R}$ & $6 \mathrm{~K}$ & $6 \mathrm{R}$ \\
\hline $\mathrm{a}_{\mathrm{R}}$ is the gas constant & &
\end{tabular}

The value for the heat of fusion was estimated from the recommended melting point given by Fee and Johnson ${ }^{2}$ and entropy of fusion equal to 4.2 eu used by Sheth and Leibowitz. ${ }^{11}$ The calculated values for the heats of fusion of $\mathrm{UC}$ and $\mathrm{PuC}_{0.88}$ were $11.68 \mathrm{kcal} / \mathrm{mol}$ and $7.88 \mathrm{kcal} / \mathrm{mol}$, respectively. The value of the heat of fusion for $\left(\mathrm{U}_{0.8} \mathrm{Pu} 0.2\right) \mathrm{C}$, calculated by linear interpolation, was equal to $10.92 \mathrm{kcal} / \mathrm{mol}$.

Usually, as temperature increases, $C_{p}$ values initially increase siowly, but, at a value of the reduced temperatúre $\left(T_{r}=T / T_{C}\right)$ equal to about 0.8 , they increase very rapidly with increasing temperature and reach an infinite value at the critical temperature. The equation sugested by Winsluw and used by us show similar behavior if a proper varlation of $\beta$ with temperature was included. Because we used a constant value of $\beta$ the heat capacity values will be too low at temperatures close to the critical temperature. However, critical temperatures, $T_{c}$, for carbides are not known. From the values given by Kirshenbaum et al., 6 one can calculate that the average ratio of melting point to critical temperature for alkali halides is equal to about 3.5 . Using this ratio, we estimated the critical temperatures for $U C, \mathrm{PuC}_{0.88}$, and $\left(\mathrm{U}_{0.8} \mathrm{Pu}_{0.2}\right.$ ) C to be 9750,6550 , and $9653 \mathrm{~K}$, respectively. Based on the above information and using equation 5 and values given in Table 4, we calculated the heat capacity and enthalpy data for UC (up to $7800 \mathrm{~K}$ ) and $\mathrm{PuC} 0.88$ (up to $5200 \mathrm{~K})$; these values are given in Tables 5 and 6 , respectively. 
TABLE 5. Estimated Values of Heat Capacity and Enthalpy of UC in Liquid Region.

\begin{tabular}{|c|c|c|c|c|c|c|c|c|}
\hline $\begin{array}{c}\text { Temp, } \\
\text { K }\end{array}$ & $\begin{array}{c}\mathrm{C}_{\mathrm{p}}^{\circ}, \\
\mathrm{cal} /(\mathrm{mol})(\mathrm{K})\end{array}$ & $\begin{array}{l}\mathrm{H}_{\mathrm{T}}^{\circ}-\mathrm{H}_{298}, \\
\mathrm{cal} / \mathrm{mol}\end{array}$ & $\begin{array}{c}\text { Temp, } \\
\mathrm{K}\end{array}$ & $\begin{array}{c}\mathrm{C}_{\mathrm{p}}^{\circ} \\
\mathrm{cal} /(\mathrm{mol})(\mathrm{K})\end{array}$ & $\begin{array}{l}\mathrm{H}_{\mathrm{T}}^{\circ}-\mathrm{H}_{298}, \\
\mathrm{cal} / \mathrm{mol}\end{array}$ & $\begin{array}{c}\text { Temp, } \\
\mathrm{K}\end{array}$ & $\begin{array}{c}\mathrm{C}_{\mathrm{p}}^{\circ} \\
\mathrm{cal} /(\mathrm{mol})(\mathrm{K})\end{array}$ & $\begin{array}{l}\mathrm{H}_{\mathrm{T}}^{\circ}-\mathrm{H}_{298}^{\circ}, \\
\mathrm{cal} / \mathrm{mol}\end{array}$ \\
\hline 2780 & 17.10 & 52621 & 4500 & 21.31 & 84792 & 6200 & 23.47 & 122005 \\
\hline 2800 & 17.14 & 52963 & 4600 & 20.49 & 86832 & 6300 & 23.66 & 124361 \\
\hline 2900 & 17.33 & 54687 & 4700 & 20.68 & 88891 & 6400 & 23.85 & 126737 \\
\hline 3000 & 17.51 & 56429 & 4800 & 20.87 & 90968 & 6500 & 24.03 & 129130 \\
\hline 3100 & 17.70 & 58189 & 4900 & 21.05 & 93064 & 6600 & 24.22 & 131543 \\
\hline 3200 & 17.88 & 59968 & 5000 & 21.24 & 95178 & 6700 & 24.41 . & 133974 \\
\hline 3300 & 18.07. & 61766 & 5100 & 21.42 & 97311 & 6800 & 24.59 & 136424 \\
\hline 3400 & 18.26 & 63582 & 5200 & 21.61 & 99463 & 6900 & 24.78 & 138892 \\
\hline 3500 & 18.44 & 65417 & 5300 & 21.80 & 101633 & 7000 & 24.96 & 141379 \\
\hline 3600 & 18.63 & 67271 & 5400 & 21.93 & 103822 & 7100 & 25.15 & 143885 \\
\hline 3700 & 18.82 & 69143 & 5500 & 22.17 & 106030 & 7200 & 25.34 & 146409 \\
\hline 3800 & 19.00 & 71034 & 5600 & 22.36 & 108256 & 7300 & 25.52 & 148952 \\
\hline 3900 & 19.19 & 72944 & 5700 & 22.54 & 110501 & 7400 & 25.71 & $\cdot 151514$ \\
\hline 4000 & 19.38 & 74872 & 5800 & 22.73 & 112764 & 7500 & 25.90 & 154094 \\
\hline 4100 & 19.56 & 76819 & 5900 & 22.91 & 115047 & 7600 & 26.08 & 156693 \\
\hline 4200 & 19.75 & 78784 & 6000 & 23.10 & 117347 & 7700 & 26.27 & 159310 \\
\hline 4300 & 19.93 & 80768 & 6100 & 23.29 & 119667 & 7800 & 26.45 & 161946 \\
\hline 4400 & 20.12 & 82771 & & & & & & \\
\hline
\end{tabular}

aalues are based on:

$$
\begin{aligned}
& \mathrm{C}_{\mathrm{P}}^{\circ}=11.9232+1.8629 \times 10^{-3} \mathrm{~T} \\
& \mathrm{H}_{\mathrm{T}}^{\circ}-\mathrm{H}_{298}^{\circ}=12275.9+11.9232 \mathrm{~T}+9.3145 \times 10^{-4} \mathrm{~T}^{2}
\end{aligned}
$$


TABLE 6. Estimated Values of Heat Capacity and Enthalpy of $\mathrm{PuC}_{0.88}$ in Liquid Region.

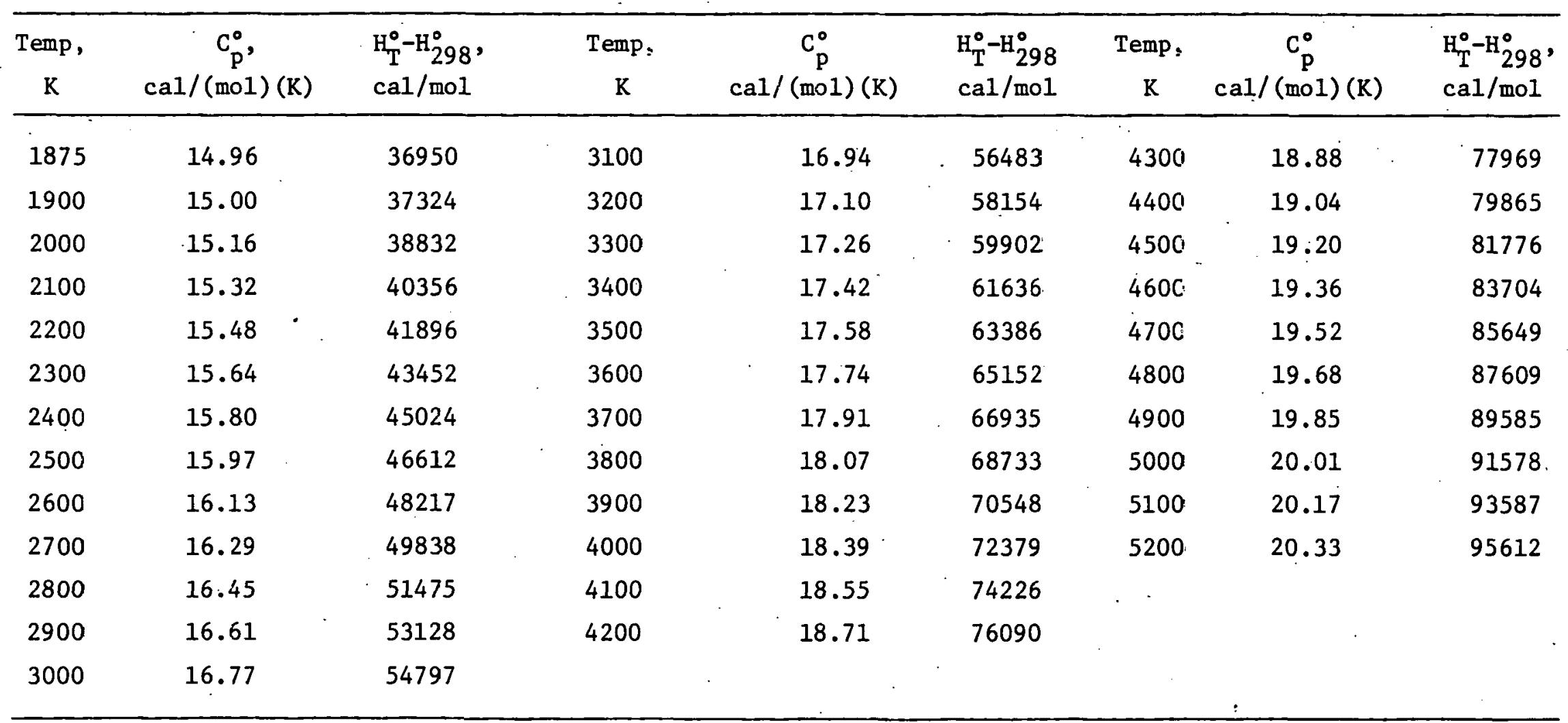

aalues are based on:

$$
\begin{aligned}
& \mathrm{C}_{\mathrm{p}}^{\circ}=11.9232+1.6168 \times 10^{-3} \mathrm{~T} \\
& \mathrm{H}_{\mathrm{T}}^{\circ}-\mathrm{H}_{298}^{\circ}=11752+11.9232 \mathrm{~T}+3.084 \times 10^{-4} \mathrm{~T}^{2}
\end{aligned}
$$


Liquid heat capacity values calculated in this way show a very large decrease in heat capacity on melting for $\mathrm{PuC}_{0.88}$ (from 35.68 to 14.96) as compared with UC (which decreases from 20.93 to 17.10). Clearly, further analysis of the $\mathrm{PuC}_{0,88}$ case is warranted. In the absence of additional experimental information, the values of $\mathrm{C}_{\mathrm{P}}^{\circ}$ and $\mathrm{H}_{\mathrm{T}}^{\circ}-\mathrm{H}_{298} 98$ reported here should be used with due caution.

By assuming an ideal solution behavior, heat capacity (and by integration, enthalpy) data for $\left(\mathrm{U}_{0.8} \mathrm{Pu}_{0.2}\right) \mathrm{C}$ were calculated using data from Tables 5 and 6 . other calculations were made in which values for the mixed carbide given in Table 4 were used in applying Winslow's equation (e.g. equation 5). The values for heat capacity and enthalpy obtained by using Eq. 5 agreed within $\pm 1 \%$ with the values obtained by assuming an ideal solution behavior. The values calculated from Winslow's equation are given in Table 7 .

Vapor Pressure of Carbide Fuels

Consideration of the vapor pressure over carbide fuel material is complicated because of the various gaseous species that may exist over the solid and liquid. Moreover, available measurements in the low-temperature region are not complete and consistent, which makes high-temperature extrapolation and estimation very difficult. The well-known law-of corresponding states implies that substances are characterized by their thermodynamic critical properties: critical temperature, $\mathrm{T}_{c}$, critical density, $\rho_{c}$, (or critical volume, $V_{c}$ ), critical pressure, $P_{c}$, and critical compressibility factor, $\mathrm{Z}_{\mathrm{C}}$; and that materials under the same reduced conditions of temperature, pressure, and volume will, have similar behavior. This approximate relation has been used by several investigators first to estimate the critical properties of reactor fuel materials and then to apply the generalized vapor-pressure correlations given by Hougen, Watson, and Ragatz. ${ }^{12}$ Miller 13 has given a detailed report on various empirical and semi-theoretical approaches that have been used in the literature for estimation purposes. In general, the low-temperature vapor-pressure equations are obtained by fitting experimental data determined by effusion, transpiration, or massspectrometric methods. These data are thus sensitive to the details of stoichiometry, system pressure and the materials of containment used for the experiment. For reactor safety analysts, these equations must often be extrapolated six to nine orders of magnitude or higher in pressure than that experimentally measured. Such extrapolations are often reasonally accurate for common materials, but, at higher temperatures, effects such as dissociation, excited states, and ionization would be expected to complicate behavior for reactor fuel materials. Moreover, in using low-temperature vapor-pressure data to estimate high-temperature values, there is the additional danger that vapor spccice which may be important at high temperatures will not be adequately represented by the lower temperature data. The empirical approach that we have taken is to extrapolate equations derived from basic thermodynamic data for the pressures of individual vapor species and to sum the pressures to give the total pressure above the condensed phase. In making these extrapolations above the melting point, an adjustment is required for the heat of fusion. Following a suggestion of $P$. Blackburn, 14 we have corrected each partial pressure equation by a multiple of the heat of fusion 
TABLE 7. Estimated Values of Heat Capacity anc

Enthalpy of $\left(\mathrm{U}_{0.8} \mathrm{Pu}_{0.2}\right) \mathrm{C}$ in Liquid Region.

\begin{tabular}{|c|c|c|c|c|c|c|c|c|}
\hline $\begin{array}{c}\text { Temp, } \\
\text { K }\end{array}$ & $\begin{array}{c}\mathrm{C}_{\mathrm{P}}^{\circ} \\
\mathrm{cal} /(\mathrm{mol})(\mathrm{K})\end{array}$ & $\begin{array}{l}\mathrm{H}_{\mathrm{T}}^{\circ}-\mathrm{H}_{298}^{\circ}, \\
\mathrm{cal} / \mathrm{nol}\end{array}$ & $\begin{array}{c}\text { Temp, } \\
\mathrm{K} .\end{array}$ & $\begin{array}{c}\mathrm{C}_{\mathrm{P}}^{\circ} \\
\mathrm{cal} /(\mathrm{mol})(\mathrm{K})\end{array}$ & $\begin{array}{l}\mathrm{H}_{\mathrm{T}}^{\circ}-\mathrm{H}_{298}^{\circ} \\
\mathrm{cal} / \mathrm{mo} \cdot 1\end{array}$ & $\begin{array}{c}\text { Temp, } \\
\mathrm{K}\end{array}$ & $\begin{array}{c}\mathrm{C}_{\mathrm{P}}^{\circ} \\
\mathrm{cal} /(\mathrm{mol})(\mathrm{K})\end{array}$ & $\begin{array}{l}\mathrm{H}_{\mathrm{T}}^{0}-\mathrm{H}_{298}^{\circ} \\
\mathrm{cal} / \mathrm{mol}\end{array}$ \\
\hline 2758 & $\therefore 17.01$ & 50371 & 4500 & 20.23 & 82809 & 6200 & 23.37 & 119865 \\
\hline 2800 & 17.09 & 51087 & 4600 & 20.41 & 84841 & 6300 & 23.55 & 122211 \\
\hline 2900 & $17 . .28$ & 52806 & 4700 & 20.60 & 86892 & 6400 & 23.74 & 124576 \\
\hline 3000 & .17 .46 & 54542 & 4800 & 20.78 & 88961 & 6500 & 23.92 & 126958 \\
\hline 3100 & 17.65 & 56298 & 4900 & 20.97 & 91048 & 6600 & 24.11 & 129360 \\
\hline 3200 & 17.83 & 58071 & 5000 & 21.15 & 93154 & 6700 & 24.29 & 131779 \\
\hline 3300 & 18.01 & 5986.3 & 5100 & 21.34 & 95279 & 6800 & 24.47 & 134217 \\
\hline 3400 & 18.20 & $616 \pi 4$ & 5200 & 21.52 & 97422 & 6900 & 24.65 & 136674 \\
\hline 3500 & 18.38 & $635 C 3$ & 5300 & 21.71 & 99583 & 7000 & 24.84 & 139149 \\
\hline 3600 & 18.57 & 65351 & 5400 & 21.89 & 101763 & 7100 & 25.03 & 141643 \\
\hline 3700 & 18.75 & 67217 & 5500 & 22.08 & 103961 & 7200 & 25.21 & 144155 \\
\hline 3800 & 18.94 & 69101 & 5600 & 22.26 & 106178 & 7300 & 25.40 & 146685 \\
\hline 3900 & 19.12 & 71004 & 5700 & 22.44 & 108413 & 7400 & 25.58 & 149234 \\
\hline 4000 & 19.31 & 72925 & 5800 & 22.63 & 110666 & 7500 & 25.77 & 151801 \\
\hline 4100 & 19.49 & 74865 & 5900 & 22.81 & 112938 & 7500 & 25.95 . & 154387 \\
\hline 4200 & 19.68 & 76824 & 6000 & 23.00 & 115229 & 7700 & 26.14 & 156992 \\
\hline 4300 & 19.86 & 78800 & 6100 & 23.18 & 117538 & 7800 & 26.32 & 159614 \\
\hline 4400 & 20.04 & 80796 & & & & & & \\
\hline
\end{tabular}

\footnotetext{
aalues are based on:
}

$$
\begin{aligned}
& \mathrm{C}_{\mathrm{p}}^{\circ}=11.9232+1.8457 \times 10^{-3} \mathrm{~T} \\
& \mathrm{H}_{\mathrm{T}}^{\circ}-\mathrm{H}_{298}^{\circ}=10467.1+11.9232 \mathrm{~T}+9.2285 \times 10^{-4} \mathrm{~T}^{2}
\end{aligned}
$$


$\left(\Delta \mathrm{H}_{\mathrm{f}}\right)$, depending on the number of condensed-phase molecules that are required to form the gaseous molecule, e $g ., \Delta \mathrm{H}_{\mathrm{f}}$ for $\mathrm{U}(\mathrm{g}), 2 \Delta \mathrm{H}_{\mathrm{f}}$ for $\mathrm{C}_{2}(\mathrm{~g}), 3 \Delta \mathrm{H}_{\mathrm{f}}$ for $\mathrm{C}_{3}(\mathrm{~g})$.

In the recent critical evaluation of low-temperature vapor-pressure data of UC, Tetenbaum et $a Z$. 1 assumed the existence of monatomic uranium species and $\mathrm{UC}_{2}(\mathrm{~g}), \mathrm{C}_{1}(\mathrm{~g}), \mathrm{C}_{2}(\mathrm{~g})$, and $\mathrm{C}_{3}(\mathrm{~g})$. In the present work, we have added $\mathrm{C}_{4}(\mathrm{~g})$. Tetenbaum and coworkers derived equations giving the temperature dependence of the pressures of the various species. They were based on the carbon and uranium activity values given in the IAEA panel assessment ${ }^{8}$ of the U-C system. Necessary thermodynamic property values were also obtained from the IAEA panel's assessment. 8 The equations with the values calculated therefrom are given in Table 8. The contribution of the $\mathrm{C}_{4}(\mathrm{~g})$ species to the pressure was calculated on the basis of the following equations:

$$
\begin{aligned}
& 4 U C(s)=4 U(g)+C_{4}(g) \\
& 4 \Delta G_{f}^{\circ}(U, g)+\Delta G_{f}^{\circ}\left(C_{4}, g\right)-4 \Delta G_{f}^{\circ}(U C, s)=-R T \ln \left(P_{U}^{4} P_{C_{4}}\right)
\end{aligned}
$$

By using the free energy of formation values for $U C(s)$ and $U(g)$ from the report of Tetenbaum and coworkers ${ }^{1}$ and for $\mathrm{C}_{4}(\mathrm{~g})$ from the JANAF tables, the following equation was derived for partial pressure of $\mathrm{C}_{4}(\mathrm{~g})$ over $\mathrm{UC}(\mathrm{s})$

$$
\log \mathrm{P}_{\mathrm{C}_{4}}=12.23-\frac{63800}{\mathrm{~T}}
$$

Values calculated from Eq. 8 are given along with the recommended lowtemperature data of Tetenbaum and coworkers in Table 8 .

By fitting the standard form of the vapor pressure versus temperature relation to the total pressure data given in Table 8 , the following equation was obtained:

$$
\begin{aligned}
& \log \mathrm{P}_{\mathrm{T}}=1.3681-\frac{26993}{\mathrm{~T}}+1.0995 \log \mathrm{T} \\
& \left(\mathrm{P}_{\mathrm{T}} \text { in atm, } \mathrm{T} \text { in } \mathrm{K}\right)
\end{aligned}
$$

Beyond the melting point, one must correct the equation representing the vapor pressure for the heat of fusion in order to extrapolate total pressure over UC into the liquid region. As mentioned earlier, according to $P$. Blackburn ${ }^{14}$, a reasonable approach is to correct the slope of the partial pressure curve of each species by an appropriate multiple of the heat of fusion of UC at the melting point and then to use the corrected equation to extrapolate beyond the melting point. The corrected equations for the 1iquid region are as follows:

$$
\begin{aligned}
& \log \mathrm{P}_{U}=4.58-\frac{25400}{\mathrm{~T}} \\
& \log \mathrm{P}_{U C_{2}}=6.45-\frac{36100}{\mathrm{~T}} \\
& \log \mathrm{P}_{\mathrm{C}_{1}}=7.44-\frac{37500}{\mathrm{~T}}
\end{aligned}
$$


TABLZ 8. Low-Temperature Vapor Pressure Data of LC

\begin{tabular}{|c|c|c|c|c|c|c|c|}
\hline $\begin{array}{l}\text { Temp, } \\
\text { K }\end{array}$ & $\mathrm{P}_{\mathrm{U}}^{\mathrm{P}}{ }^{\mathrm{a}}$ & ${ }_{\text {atm }}^{{ }^{\mathrm{P}_{1}}}{ }^{\mathrm{a}}$, & ${ }_{\text {atm }}^{\mathrm{P}_{2}}{ }^{\mathrm{a}}$, & ${ }_{\mathrm{atm}}^{\mathrm{P}_{3}}{ }^{\mathrm{a}}$ & $\begin{array}{l}\mathrm{P}_{\mathrm{C}_{4}}, \\
\text { atm }\end{array}$ & ${ }_{\mathrm{atm}}^{\mathrm{F}_{\mathrm{UC}}}{ }^{\mathrm{a}}$ & $\begin{array}{l}\mathrm{P}_{\mathrm{T}}^{\mathrm{b}}=\text { Total } \\
\text { Pressure, atm }\end{array}$ \\
\hline 2000 & $3.16 \times 10^{-9}$ & $2.04 \times 10^{-12}$ & $8.51 \times 10^{-15}$ & $6.31 \times 10^{-15}$ & $2.25 \times 10^{-20}$ & $4.90 \times 10^{-13}$ & $3.16 \times 10^{-9}$ \\
\hline 2100 & $1.47 \times 10^{-8}$ & $1.84 \times 10^{-11}$ & $1.21 \times 10^{-13}$ & $9.11 \times 10^{-14}$ & $7.41 \times 10^{-19}$ & $4.69 \times 10^{-12}$ & $1.47 \times 10^{-8}$ \\
\hline 2200 & $5.93 \times 10^{-8}$ & $1.36 \times 10^{-10}$ & $1.35 \times 10^{-12}$ & $1.03 \times 10^{-12}$ & $1.78 \times 10^{-17}$ & $3.65 \times 10^{-11}$ & $5.94 \times 10^{-8}$ \\
\hline 2300 & $2.12 \times 10^{-7}$ & $8.42 \times 10^{-10}$ & $1.22 \times 10^{-11}$ & $9.46 \times 10^{-12}$ & $3.23 \times 10^{-16}$ & $2.38 \times 10^{-10}$ & $2.13 \times 10^{-7}$ \\
\hline 2400 & $6.81 \times 10^{-7}$ & $4.43 \times 10^{-9}$ & $9.19 \times 10^{-11}$ & $7.22 \times 10^{-11}$ & $4.62 \times 10^{-15}$ & $1.33 \times 10^{-9}$ & $6.87 \times 10^{-7}$ \\
\hline 2500 & $2.00 \times 10^{-6}$ & $2 . \cos \times 10^{-8}$ & $5.89 \times 10^{-1 C}$ & $4.68 \times 10^{-10}$ & $5.34 \times 10^{-14}$ & $6.46 \times 10^{-9}$ & $2.02 \times 10^{-6}$ \\
\hline
\end{tabular}

Q Values are calculated based on the following equations given by Tetenbaum and coworkers ${ }^{1}$ :

$$
\begin{aligned}
& \log \mathrm{P}_{U}=5.5-\frac{28000}{\mathrm{~T}} \\
& \log \mathrm{P}_{\mathrm{C}_{1}}=8.36-\frac{40100}{\mathrm{~T}} \\
& \log \mathrm{P}_{\mathrm{C}_{2}}=10.13-\frac{48400}{\mathrm{~T}} \\
& \log \mathrm{P}_{\mathrm{C}_{3}}=10.15-\frac{48700}{\mathrm{~T}} \\
& \log \mathrm{P}_{U \mathrm{UC}_{2}}=8.29^{\circ}-\frac{41200}{\mathrm{~T}} \\
& { }^{\mathrm{b}} \mathrm{P}_{\mathrm{T}}=\mathrm{P}_{\mathrm{U}}+\mathrm{P}_{\mathrm{UC}_{2}}+\mathrm{P}_{\mathrm{C}_{1}}+\mathrm{P}_{\mathrm{C}_{2}}+\mathrm{P}_{\mathrm{C}_{3}}+\mathrm{P}_{\mathrm{C}_{4}}
\end{aligned}
$$




$$
\begin{aligned}
& \log P_{C_{2}}=8.29-\frac{43300}{R} \\
& \log P_{C_{3}}=7.40-\frac{41000}{T} \\
& \log P_{C_{4}}=8.56-\frac{53600}{T}
\end{aligned}
$$

Using these equations and the relation

$$
\text { Total pressure }=\mathrm{P}_{\mathrm{T}}=\mathrm{P}_{\mathrm{U}}+\mathrm{P}_{\mathrm{C}_{1}}+\mathrm{P}_{\mathrm{C}_{2}}+\mathrm{P}_{\mathrm{C}_{3}}+\mathrm{P}_{\mathrm{C}_{4}}+\mathrm{P}_{\mathrm{UC}_{2}}
$$

we calculated values for various partial pressures and total pressure as a function of temperature. These are given in Table 9.

Fitting the standard form of the vapor pressure versus temperature relation to the total pressure data given in Table 9, one obtains the following equation:

$$
\begin{aligned}
& \log \mathrm{P}_{\mathrm{T}}=-24.0089-\frac{18132}{\mathrm{~T}}+7.5425 \log \mathrm{T} \\
& \left(\mathrm{P}_{\mathrm{T}} \text { in atm, } \mathrm{T} \text { in } \mathrm{K}\right)
\end{aligned}
$$

From the values given in Table 9, the normal boiling point of UC was calculated to be $4814 \mathrm{~K}$.

Because of the limited amount of data avallable on the vaporization behavior of well-characterized U-Pu-C compositions, calculations were made by Tetenbaum and coworkers ${ }^{1}$ to estimate the total pressure of actinide and carbon-bearing species over the U-Pu-C system. Those calculations were based on the equations given by Potter et a $.5,15,16$ Necessary thermodynamic property values were obtained either from the IAEA Panel's assessment or JANAF tables. In a manner similar to that for UC, Tetenbaum and coworkers assumed the existence of $\mathrm{Pu}(\mathrm{g}), \mathrm{U}(\mathrm{g}), \mathrm{UC}_{2}(\mathrm{~g}), \mathrm{C}_{1}(\mathrm{~g}), \mathrm{C}_{2}(\mathrm{~g})$, and $\mathrm{C}_{3}(\mathrm{~g})$ carbon species. Because $C_{4}(g)$ is expected to make a significant contribution at very high temperatures, we have added this to the list. The pertinent derived equations for $\mathrm{C}_{4}(\mathrm{~g})$ are as follows:

$$
\begin{aligned}
& 9\left[\mathrm{UC}_{1.5}, \mathrm{~s}\right]_{\mathrm{PuC}_{1.5}}=\mathrm{C}_{4}(\mathrm{~g})+8[\mathrm{UC}, \mathrm{s}]_{\mathrm{PuC}} \\
& 8 \Delta \mathrm{G}_{\mathrm{f}}^{\circ}(\mathrm{UC}, \mathrm{s})+\Delta \mathrm{G}_{\mathrm{f}}^{\circ}\left(\mathrm{C}_{4}, \mathrm{~g}\right)-8 \Delta \mathrm{G}_{\mathrm{f}}^{\circ}\left(\mathrm{UC}_{1.5}, \mathrm{~s}\right)=-\mathrm{RT} \ln \frac{\mathrm{P}_{\mathrm{C}_{4}}[\mathrm{UC}]^{8}}{\left[\mathrm{UC}_{1.5}\right]^{8}}
\end{aligned}
$$

When the two-phase region is expressed by $U_{1-x_{1}} P u_{x_{1}} c-U_{1-x_{2}} P u_{x_{2}} C_{1.5}$, the
above equation reduces to

$$
\begin{aligned}
\text { RT In } P_{C_{4}}=-8 \Delta G_{f}^{\circ}(U C, s)-\Delta G_{f}^{\circ}\left(C_{4}, g\right) & +8 \Delta G_{f}^{\circ}\left(U C_{1.5}, s\right)-8 R T \ln \left(1-x_{1}\right) \\
& +8 R T \ln \left(1-x_{2}\right)
\end{aligned}
$$

By using the information provided by Tetenbaum and coworkers ${ }^{l}$ on the free energies of formation and the values of $x_{1}$ and $x_{2}$, and using $\Delta G_{f}^{\circ}$ for $C_{4}(g)$ 
TABLE 9. Estimated Vapor Pressure Data of UC

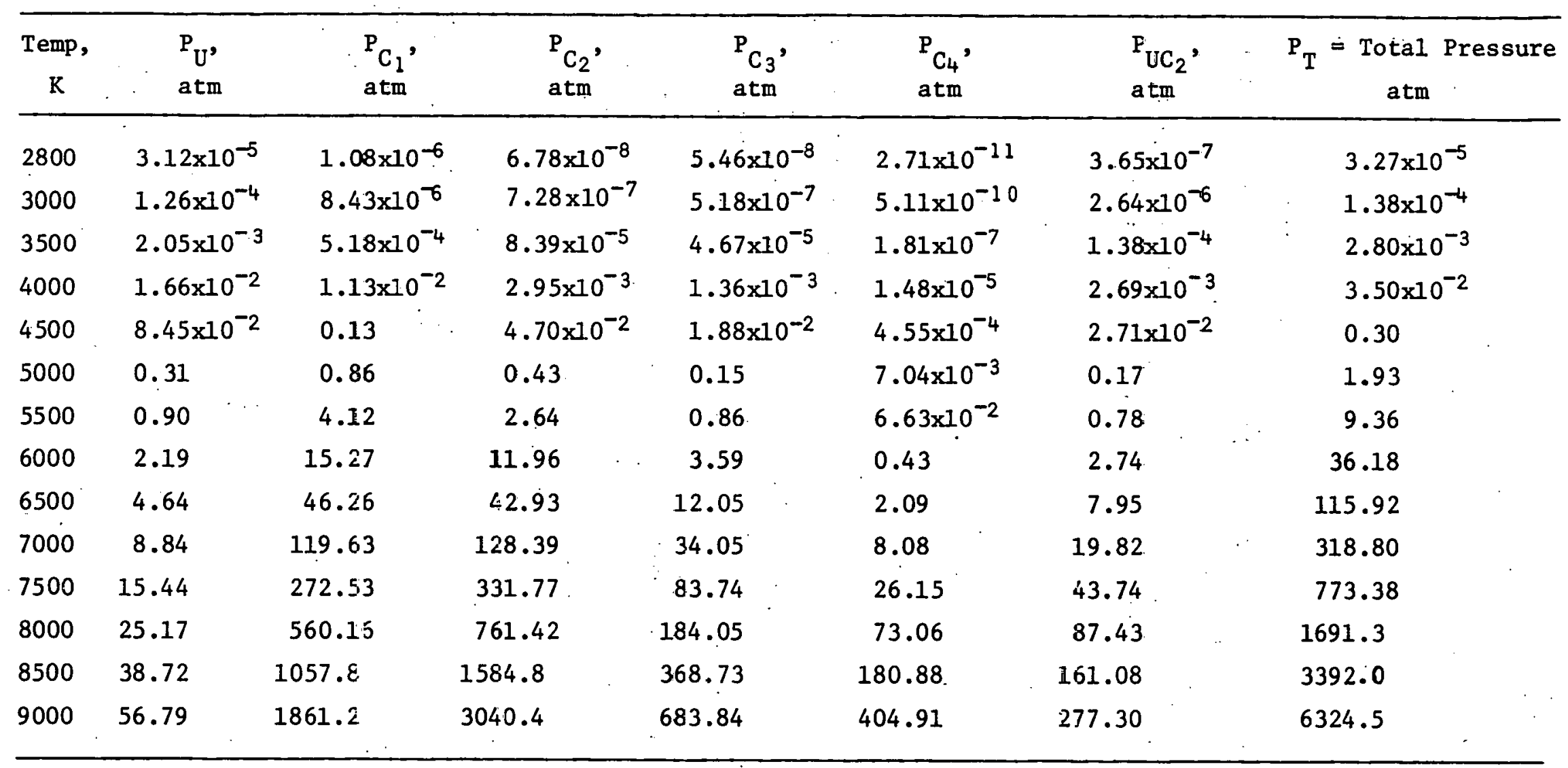


from the JANAF tables, the following equation was obtalned:

$$
\log \mathrm{P}_{\mathrm{C}_{4}}=10.16-\frac{52200}{\mathrm{~T}}
$$

Values calculated from Eq. 21, along with the recommended low-temperature data by Tetenbaum and coworkers, ${ }^{1}$ are given in Table 10.

By fitting the standard form of vapor pressure versus temperature relation to the total pressure data given in Table 10, the following equation was obtained.

$$
\begin{aligned}
& \log \mathrm{P}_{\mathrm{T}}=2.9716-\frac{18940}{\mathrm{~T}}+0.17958 \log \mathrm{T} \\
& \left(\mathrm{P}_{\mathrm{T}} \text { in atm, } \mathrm{T} \text { in } \mathrm{K}\right)
\end{aligned}
$$

Using the equations given above and following a similar approach to that which was used for UC to correct for the heat of fusion, one obtains the following equations in the liquid region:

$$
\begin{aligned}
& \log \mathrm{P}_{\mathrm{Pu}}=2.77-\frac{16700}{\mathrm{~T}} \\
& \log \mathrm{P}_{\mathrm{U}}=5.05-\frac{28500}{\mathrm{~T}} \\
& \log \mathrm{P}_{\mathrm{C}_{1}}=7.26-\frac{35500}{\mathrm{~T}} \\
& \log \mathrm{P}_{\mathrm{C}_{2}}=8.01-\frac{39400}{\mathrm{~T}} \\
& \log \mathrm{P}_{\mathrm{C}_{3}}=6.98-\frac{35200}{\mathrm{~T}} \\
& \log \mathrm{P}_{\mathrm{C}_{4}}=6.70-\frac{42700}{\mathrm{~T}} \\
& \log \mathrm{P}_{\mathrm{UC}_{2}}=6.58-\frac{35000}{\mathrm{~T}}
\end{aligned}
$$

Using the above equations along with an equation similar to equation 16 , we calculated values for various partial pressure as a function of temperature. These are listed in Table 11.

Fitting the standard form of the vapor pressure versus temperature relation to the total pressure data given in Table 11, one obtains the following equation:'

$$
\begin{aligned}
& \log \mathrm{P}_{\mathrm{T}}=-38.8409-\frac{6157.4}{\mathrm{~T}}+10.985 \log \mathrm{T} \\
& \left(\mathrm{P}_{\mathrm{T}} \text { in atm, } \mathrm{T} \text { in } \mathrm{K}\right)
\end{aligned}
$$

From the values given in Table 11 , the normal bolling. point of $\left(\mathrm{U}_{0.8} \mathrm{Pu}_{0.2}\right) \mathrm{C}$ was calculated to be $4558 \mathrm{~K}$.

As in the case of the mixed carbide, measurements for vapor pressure of $\mathrm{PuC}_{0.88}$ are not complete. Tetenbaum and coworkers ${ }^{1}$ calculated plutonium and carbon pressures over the monocarbide phase from the appropriate values of 
TABLE 10. Low-Temperature Vapor Pressure Data of $\left(\mathrm{U}_{0.8} \mathrm{Pu} \mathrm{u}_{0.2}\right) \mathrm{C}$

\begin{tabular}{|c|c|c|c|c|c|c|c|c|}
\hline $\begin{array}{c}\text { Temp, } \\
\mathrm{K}\end{array}$ & $\begin{array}{l}\mathrm{P}_{\mathrm{U}}^{\mathrm{a}} \\
\text { atm }\end{array}$ & $\begin{array}{l}P_{P \cdot d}{ }^{a} \\
a t m\end{array}$ & $\begin{array}{l}\mathrm{P}_{\mathrm{C}_{1}}{ }^{\mathrm{a}} \text {, } \\
\text { atm }\end{array}$ & $\begin{array}{l}\mathrm{P}_{\mathrm{C}_{2}}^{\mathrm{a}}, \\
\mathrm{atm}\end{array}$ & $\underset{\mathrm{C}_{3}}{\mathrm{P}^{\mathrm{atm}}}$ & ${ }_{\mathrm{C}_{4}}^{\mathrm{P}_{\text {atm }}}$, & $\begin{array}{l}\mathrm{P}_{\mathrm{UC}_{2}}^{\mathrm{a}} \\
\mathrm{atm}\end{array}$ & $\begin{array}{c}\dot{\mathrm{P}}_{\mathrm{T}}^{\mathrm{b}}=\text { Total } \\
\text { Pressure, atm }\end{array}$ \\
\hline 1500 & $2.19 \times 10^{-15}$ & $8.21 \times 10^{-10}$ & $7.30 \times 10^{-18}$ & $1.88 \times 10^{-20}$ & $2.07 \times 10^{-19}$ & $2.18 \times 10^{-25}$ & $5.76 \times 10^{-19}$ & $8.21 \times 10^{-10}$ \\
\hline 1600 & $4.23 \times 10^{-14}$ & $5.12 \times 10^{-9}$ & $2.77 \times 10^{-16}$ & $1.31 \times 10^{-18}$ & $1.21 \times 10^{-17}$ & $3.27 \times 10^{-23}$ & $2.63 \times 10^{-17}$ & $5.12 \times 10^{-9}$ \\
\hline 1700 & $5.77 \times 10^{-13}$ & $2.58 \times 10^{-8}$ & $6.84 \times 10^{-15}$ & $5.51 \times 10^{-17}$ & $4.37 \times 10^{-16}$ & $2.72 \times 10^{-21}$ & $7.65 \times 10^{-16}$ & $2.58 \times 10^{-8}$ \\
\hline 1800 & $5.88 \times 10^{-12}$ & $1.08: 10^{-7}$ & $1.18 \times 10^{-13}$ & $1.53 \times 10^{-15}$ & $1.06 \times 10^{-14}$ & $1.39 \times 10^{-19}$ & $1.53 \times 10^{-14}$ & $1.08 \times 10^{-7}$ \\
\hline 1900 & $4.70 \times 10^{-11}$ & $3.91 \times 10^{-7}$ & $1.52 \times 10^{-12}$ & $3.01 \times 10^{-14}$ & $1.84 \times 10^{-13}$ & $4.66 \times 10^{-18}$ & $2.24 \times 10^{-1.3}$ & $3.91 \times 10^{-7}$ \\
\hline 2000 & $3.05 \times 10^{-10}$ & $1.24 \times 10^{-6}$ & $1.51 \times 10^{-11}$ & $4.38 \times 10^{-13}$ & $2.40 \times 10^{-12}$ & $1.10 \times 10^{-16}$ & $2.50 \times 10^{-12}$ & $1.24 \times 10^{-6}$ \\
\hline 2100 & $1.66 \times 10^{-9}$ & $3.54 \times 10^{-6}$ & $1.21 \times 10^{-10}$ & $4.95 \times 10^{-12}$ & $2.46 \times 10^{-11}$ & $1.93 \times 10^{-15}$ & $2.22 \times 10^{-11}$ & $3.54 \times 10^{-6}$ \\
\hline 2200 & $7.72 \times 10^{-9}$ & $9.16 \times 10^{-6}$ & $7.96 \times 10^{-10}$ & $4.48 \times 10^{-11}$ & $2.03 \times 10^{-10}$ & $2.61 \times 10^{-14}$ & $1.61 \times 10^{-10}$ & $9.17 \times 10^{-6}$ \\
\hline 2300 & $3.15 \times 10^{-8}$ & $2.18 \times 10^{-5}$ & $4.47 \times 10^{-9}$ & $3.35 \times 10^{-10}$ & $1.40 \times 10^{-9}$ & $2.81 \times 10^{-13}$ & $9.87 \times 10^{-10}$ & $2.19 \times 10^{-5}$ \\
\hline 2400 & $1.14 \times 10^{-7}$ & $4.84 \times 10^{-5}$ & $2.17 \times 10^{-8}$ & $2.12 \times 10^{-9}$ & $8.20 \times 10^{-9}$ & $2.49 \times 10^{-12}$ & $5.20 \times 10^{-9}$ & $4.85 \times 10^{-5}$ \\
\hline 2500 & $3.73 \times 10^{-7}$ & $1.01 \times 10^{-4}$ & $9.29 \times 10^{-8}$ & $1.15 \times 10^{-8}$ & $4.17 \times 10^{-8}$ & $1.84 \times 10^{-11}$ & $2.40 \times 10^{-8}$ & $1.01 \times 10^{-4}$ \\
\hline
\end{tabular}

avalues are calculated based on the following equations given by Tetenbaum and Coworkers ${ }^{1}$ :

$$
\begin{aligned}
& \log P_{P_{U}}=3.63-\frac{19100}{T} \\
& \log P_{U}=5.92-\frac{30900}{T} \\
& \log P_{C_{1}}=8.13-\frac{37900}{T} \\
&{ }_{P_{T}}=P_{P_{U}}+P_{U}+P_{C_{1}}+P_{C_{2}}+P_{C_{3}}+P_{C_{4}}+P_{U C_{2}}
\end{aligned}
$$

$$
\begin{aligned}
& \log P_{C_{2}}=9.75-\frac{44200}{T} \\
& \log P_{C_{3}}=9.58-\frac{42400}{T} \\
& \log P_{U_{C_{2}}}=8.31-\frac{39800}{T}
\end{aligned}
$$


TABLE 11. Estimated Vapor Pressure Data of $\left(\mathrm{U}_{0.8} \mathrm{Pu}_{0.2}\right) \mathrm{C}$

\begin{tabular}{|c|c|c|c|c|c|c|c|c|c|}
\hline $\begin{array}{c}\text { Temp, } \\
\mathrm{K}\end{array}$ & $\begin{array}{l}\mathrm{P}_{\mathrm{Pu}}, \\
\text { atm }\end{array}$ & ${ }_{\text {atm }}^{\mathrm{P}_{\mathrm{U}}}$ & ${ }_{\text {atm }}^{\mathrm{P}_{\mathrm{C}_{1}}}$ & $\begin{array}{l}\mathrm{P}_{\mathrm{C}_{2}}, \\
\text { atm }\end{array}$ & $\begin{array}{l}{ }_{\mathrm{C}_{3}}, \\
\text { atm }\end{array}$ & $\begin{array}{l}\mathrm{P}_{\mathrm{C}_{4}}, \\
\text { atm }\end{array}$ & $\underset{\text { atm }}{\mathrm{P}_{\mathrm{UC}_{2}} \text {, }}$ & $\begin{array}{l}\mathrm{P}_{\mathrm{T}}=\text { Tot } \\
\text { Pressure, }\end{array}$ & atm \\
\hline 2800 & $7.61 \times 10^{-6}$ & $6.42 \times 10^{-4}$ & $3.79 \times 10^{-6}$ & $8.53 \times 10^{-7}$ & $2.50 \times 10^{-6}$ & $2.83 \times 10^{-9}$ & $1.15 \times 10^{-9}$ & $6.58 \times 10^{-4}$ & \\
\hline 3000 & $3.63 \times 10^{-5}$ & $1.60 \times 10^{-3}$ & $2.66 \times 10^{-5}$ & $7.41 \times 10^{-6}$ & $1.73 \times 10^{-5}$ & $2.94 \times 10^{-8}$ & $7.85 \times 10^{-6}$ & $1.70 \times 10^{-3}$ & \\
\hline 3500 . & $8.24 \times 10^{-4}$ & $9.99 \times 10^{-3}$ & $1.30 \times 10^{-3}$ & $5.60 \times 10^{-4}$ & $8.21 \times 10^{-4}$ & $3.17 \times 10^{-6}$ & $3.66 \times 10^{-4}$ & $1.39 \times 10^{-2}$ & \\
\hline 4000 & $8.58 \times 10^{-3}$ & $3.94 \times 10^{-2}$ & $2.4 \check{i} \times 10^{-2}$ & $1.43 \times 10^{-2}$ & $1.49 \times 10^{-2}$ & $1.06 \times 10^{-4}$ & $6.54 \times 10^{-3}$ & 0.11 & \\
\hline 4500 & $5.30 \times 10^{-2}$ & 0.11 & 0.23 & 0.18 & 0.14 & $1.62 \times 10^{-3}$ & $6.15 \times 10^{-2}$ & 0.79 & 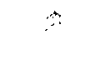 \\
\hline 5000 & 0.23 & 0.27 & 1.44 & .1 .34 & $0: 86$ & $1.44 \times 10^{-2}$ & 0.37 & 4.52 & \\
\hline 5500 & 0.75 & 0.54 & 6.37 & 7.00 & 3.76 & $8.61 \times 10^{-2}$ & 1.60 & 20.11 & \\
\hline 6000 . & 2.03 & 0.97 & 21.98 & 27.69 & 12.85 & 0.38 & 5.44 & 71.35 & \\
\hline 6500 & 4.70 & 1.59 & 62.70 & 88.70 & 36.35 & 1.35 & 15.32 & 210.70 & \\
\hline 7000 & 9.66 & 2.42 & 153.96 & 240.59 & 88.65 & 3.96 & 37.19 & 536.44 & \\
\hline 7500 & 18.05 & 3.50 & 335.40 & 571.26 & 191.96 & 10.11 & 80.21 & 1210.5 & \\
\hline 8000 & 31.17 & 4.82 & 662.91 & 1217.4 & 377.40 & 22.92 & 157.14 & 2473.8 & $\because$ \\
\hline 8500 & 50.49 & 6.39 & 1209.3 & 2373.6 & 685.27 & 47.22 & 284.45 & 4656.7 & \\
\hline 9000 & 77.50 & 8.21 & 2063.4 & 4296.8 & 1164.5 & 89.76 & 482.03 & 8182.2 & \\
\hline
\end{tabular}


the free energies of formation for the condensed phase, $\mathrm{Pu}(\mathrm{g}), \mathrm{C}_{1}(\mathrm{~g}), \mathrm{C}_{2}(\mathrm{~g})$, and $C_{3}(g)$. Their recommended data with equations for temperature dependency of plutonium- and carbon-bearing species are given in Table 12.

TABLE 12. Low-Temperature Vapor Pressure Data of $\mathrm{PuC}_{0.88}{ }^{\mathrm{a}}$

\begin{tabular}{cccccc}
\hline $\begin{array}{c}\text { Temp, } \\
\mathrm{K}\end{array}$ & $\begin{array}{c}\mathrm{P}_{\mathrm{Pu}}, \\
\mathrm{atm}\end{array}$ & $\begin{array}{c}\mathrm{P}_{\mathrm{C}_{1}}, \\
\mathrm{~atm}\end{array}$ & $\begin{array}{c}\mathrm{P}_{\mathrm{C}_{2}}, \\
\mathrm{~atm}\end{array}$ & $\begin{array}{c}\mathrm{P}_{\mathrm{C}_{3}}, \\
\mathrm{~atm}\end{array}$ & $\begin{array}{c}\mathrm{P}_{\mathrm{T}}=\text { Total } \\
\text { Pressure, atm }\end{array}$ \\
\hline 1000 & $2.10 \times 10^{-14}$ & $3.97 \times 10^{-33}$ & $2.82 \times 10^{-40}$ & $<10^{-40}$ & $2.10 \times 10^{-14}$ \\
1100 & $7.87 \times 10^{-13}$ & $1.80 \times 10^{-29}$ & $7.58 \times 10^{-36}$ & $6.20 \times 10^{-37}$ & $7.87 \times 10^{-13}$ \\
1200 & $1.61 \times 10^{-11}$ & $2.01 \times 10^{-26}$ & $3.72 \times 10^{-32}$ & $3.41 \times 10^{-33}$ & $1.61 \times 10^{-11}$ \\
1300 & $2.08 \times 10^{-10}$ & $7.63 \times 10^{-24}$ & $4.93 \times 10^{-29}$ & $4.99 \times 10^{-30}$ & $2.08 \times 10^{-10}$ \\
1400 & $1.86 \times 10^{-9}$ & $1.24 \times 10^{-21}$ & $2.34 \times 10^{-26}$ & $2.58 \times 10^{-27}$ & $1.86 \times 10^{-9}$ \\
1500 & $1.24 \times 10^{-8}$ & $1.02 \times 10^{-19}$ & $4.89 \times 10^{-24}$ & $5.78 \times 10^{-25}$ & $1.24 \times 10^{-8}$ \\
1600 & $6.55 \times 10^{-8}$ & $4.84 \times 10^{-18}$ & $5.24 \times 10^{-22}$ & $6.60 \times 10^{-23}$ & $6.55 \times 10^{-8}$ \\
1700 & $2.84 \times 10^{-7}$ & $1.46 \times 10^{-16}$ & $3.24 \times 10^{-20}$ & $4.31 \times 10^{-21}$ & $2.84 \times 10^{-7}$ \\
1800 & $1.05 \times 10^{-6}$ & $3.01 \times 10^{-15}$ & $1.27 \times 10^{-18}$ & $1.77 \times 10^{-19}$ & $1.05 \times 10^{-6}$ \\
\hline
\end{tabular}

avalues are based on:

$$
\begin{aligned}
& \log \mathrm{P}_{\mathrm{Pu}}=3.64-\frac{17300}{\mathrm{~T}} \\
& \log \mathrm{P}_{\mathrm{C}_{1}}=7.83-\frac{40200}{\mathrm{~T}} \\
& \log \mathrm{P}_{\mathrm{C}_{2}}=9.17-\frac{48700}{\mathrm{~T}} \\
& \log \mathrm{P}_{\mathrm{C}_{3}}=8.68-\frac{49400}{\mathrm{~T}}
\end{aligned}
$$

Looking at the phase diagram of the $\mathrm{Pu}-\mathrm{C}$ system given in Fig. 1, one realizes that in the absence of experimental work on single phase plutonium monocarbide, the vaporization behavior of $\mathrm{PuC}$ will be better approximated by the average properties calculated from the adjacent two-phase regions, i.e. Pu(l) $+\mathrm{PuC}$ and $\mathrm{PuC}+\mathrm{Pu}_{2} \mathrm{C}_{3}$. In the case of UC this problem did not arise since enough experimental work was done on the vaporization behavior of single phase UC. The carbon and uranium activities in single-phase UC are very well known. The low-temperature vapor-pressure data of Table 12, given by Tetenbaum et al., l represented the boundary of PuC adjacent to the $\mathrm{Pu}(l)+\mathrm{PuC}$ side of the PuC single-phase region. If the approach that was used for UC and $\left(U_{0,8} P u_{0,2}\right) C$ were to be applied to the data of Table 12, one would get unreasonabiy low values for various partial-pressure and totalpressure terms. We decided, therefore, that more reasonable values would be obtained by utilizing the properties of the two adjacent two phase regions. 


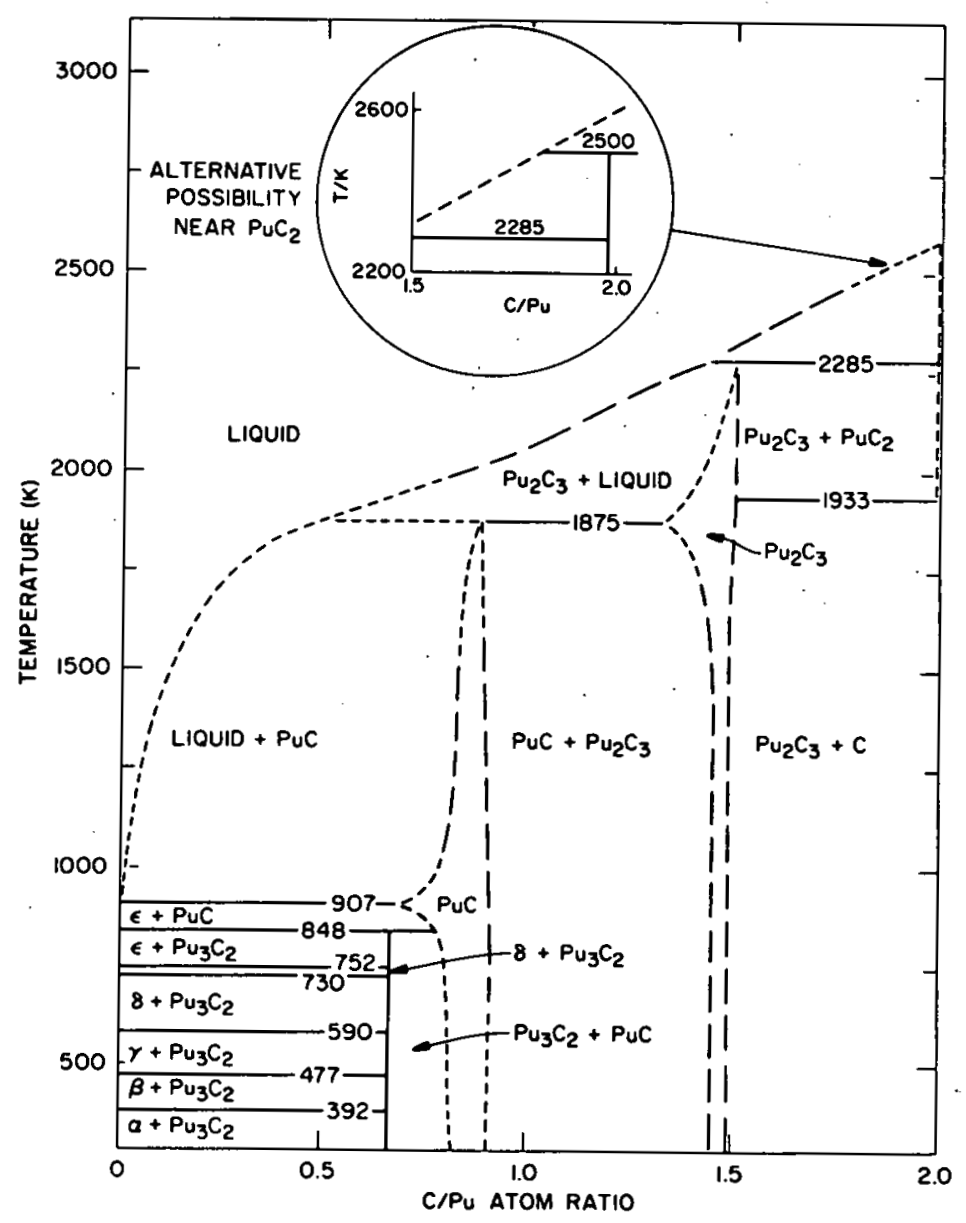

Fig. 1. Phase Diagram of the Pu-C System. ${ }^{8}$

From the report of Tctcnbaum ot al., 1 equations were also available for carbon pressures representing the two phase region corresponding to $\mathrm{PuC}+\mathrm{Pu}_{2} \mathrm{C}_{3}$. Using this information in confuction with the data of Table 12, equations were derived for the average carbon pressures in the single phase $\mathrm{PuC}$ region, which are as follows:

$$
\begin{aligned}
& \log P_{C_{1}}=8.63-\frac{17300}{T} \\
& \log P_{C_{2}}=11.00-\frac{48400}{T} \\
& \log P_{C_{3}}=11.60-\frac{48600}{T}
\end{aligned}
$$

Partial pressure of plutonium corresponding to these average carbon pressures was calculated based on the following equations:

$$
\begin{aligned}
& \mathrm{PuC}_{0.88}(s)=\mathrm{Pu}(\mathrm{g})+0.88 \mathrm{C}_{1}(\mathrm{~g}) \\
& 0.88 \Delta \mathrm{G}_{\ddagger}^{\circ}\left(\mathrm{C}_{1}, g\right)+\Delta \mathrm{G}_{f}^{\circ}(\mathrm{Pu}, \mathrm{g})-\Delta \mathrm{G}_{f}^{\circ}\left(\mathrm{PuC}_{0.88}, s\right)=-R T \ln \left(\mathrm{P}_{\mathrm{Pu}} \mathrm{P}_{1}^{0.88}\right)
\end{aligned}
$$


By using the free energy of formation values for various species reported by Tetenbaum et $a l_{1}, 1$ and the $C_{1}$ pressure calculated with Eq. 31, the following equation was calculated

$$
\log \mathrm{P}_{\mathrm{Pu}}=3.88-\frac{17300}{\mathrm{~T}}
$$

With the use of equations $31,32,33$, and 36 , low-temperature pressures were recalculated; these are given in Table 13.

TABLE 13. Low-Temperature Vapor Pressure Data of $\mathrm{PuC}_{0.88}$ (Calculated using average values derived from $\mathrm{Pu}(\ell)+\mathrm{PuC}$ and $\mathrm{PuC}+\mathrm{Pu}_{2} \mathrm{C}_{3}$ phases)

\begin{tabular}{cccccc}
\hline $\begin{array}{c}\text { Temp, } \\
\mathrm{K}\end{array}$ & $\begin{array}{c}\mathrm{P}_{\mathrm{Pu}}{ }^{\prime} \\
\mathrm{atm}\end{array}$ & $\begin{array}{c}\mathrm{P}_{\mathrm{C}_{1}}, \\
\mathrm{~atm}\end{array}$ & $\begin{array}{c}\mathrm{P}_{\mathrm{C}_{2}}, \\
\mathrm{~atm}\end{array}$ & $\begin{array}{c}\mathrm{P}_{\mathrm{C}_{3}}, \\
\mathrm{~atm}\end{array}$ & $\begin{array}{c}\mathrm{P}_{\mathrm{T}}=\text { Total Pressure } \\
\mathrm{atm}\end{array}$ \\
\hline 1000 & $3.66 \times 10^{-14}$ & $4.44 \times 10^{-32}$ & $4.38 \times 10^{-38}$ & $9.84 \times 10^{-38}$ & $3.66 \times 10^{-14}$ \\
1100 & $1.37 \times 10^{-12}$ & $1.92 \times 10^{-28}$ & $1.09 \times 10^{-33}$ & $2.58 \times 10^{-33}$ & $1.37 \times 10^{-12}$ \\
1200 & $2.81 \times 10^{-11}$ & $2.05 \times 10^{-25}$ & $5.02 \times 10^{-30}$ & $1.24 \times 10^{-29}$ & $2.81 \times 10^{-11}$ \\
1300 & $3.63 \times 10^{-10}$ & $7.50 \times 10^{-23}$ & $6.31 \times 10^{-27}$ & $1.62 \times 10^{-26}$ & $3.63 \times 10^{-10}$ \\
1400 & $3.25 \times 10^{-9}$ & $1.18 \times 10^{-20}$ & $2.86 \times 10^{-24}$ & $7.60 \times 10^{-24}$ & $3.25 \times 10^{-9}$ \\
1500 & $2.17 \times 10^{-8}$ & $9.46 \times 10^{-19}$ & $5.75 \times 10^{-22}$ & $1.57 \times 10^{-21}$ & $2.17 \times 10^{-8}$ \\
1600 & $1.14 \times 10^{-7}$ & $4.39 \times 10^{-17}$ & $5.95 \times 10^{-20}$ & $1.66 \times 10^{-19}$ & $1.14 \times 10^{-7}$ \\
1700 & $4.95 \times 10^{-7}$ & $1.29 \times 10^{-15}$ & $3.57 \times 10^{-18}$ & $1.02 \times 10^{-17}$ & $4.95 \times 10^{-7}$ \\
1800 & $1.82 \times 10^{-6}$ & $2.62 \times 10^{-14}$ & $1.36 \times 10^{-16}$ & $3.95 \times 10^{-16}$ & $1.82 \times 10^{-6}$ \\
\hline
\end{tabular}

Comparing Tables 12 and 13, one can see that the partial pressure of $\mathrm{Pu}$ and the total pressure have changed by less than a factor of 2, but the partial pressures of the carbon spectes have increased by factors of 10 to 1000. Fitting the standard form of vapor pressure versus temperature relation to $\mathrm{P}_{\mathrm{T}}$ values of Table 13 , one obtains

$\log \mathrm{P}_{\mathrm{T}}=3.8819-\frac{17319}{\mathrm{~T}}+1.7284 \times 10^{-7} \log \mathrm{T}$

Using equations $31,32,33$, and 36 , and following the approach that was used for $\mathrm{UC}$ and $\left(\mathrm{U}_{0.8} \mathrm{Pu}_{0,2}\right) \mathrm{C}$ to correct for heat of fusion, one obtains the following equations in the liquid region.

$$
\begin{aligned}
& \log \mathrm{P}_{\mathrm{Pu}_{\mathrm{u}}}=2.96-\frac{15600}{\mathrm{~T}} \\
& \log \mathrm{P}_{\mathrm{C}_{1}}=7.71-\frac{38300}{\mathrm{~T}} \\
& \log \mathrm{P}_{\mathrm{C}_{2}}=9.16-\frac{44900}{\mathrm{~T}} \\
& \log \mathrm{P}_{\mathrm{C}_{3}}=8.84-\frac{43400}{\mathrm{~T}}
\end{aligned}
$$


With the above equations, various partial pressures and the total pressure of PuC 0.88 were calculated; these are given in Table 1.4 .

The correlation of $\mathrm{P}_{\mathrm{T}}$ with temperature was calculated as:

$$
\log : P_{T}=-65.0395+\frac{4484.9}{\mathrm{~T}}+17.505 \log \mathrm{T}
$$

TABIE 14. Estimated Vapor Pressure Data of PuC 0.88

\begin{tabular}{cccccc}
\hline $\begin{array}{c}\text { Temp, } \\
\mathrm{K}\end{array}$ & $\begin{array}{c}\mathrm{P}_{\mathrm{Pu}}, \\
\mathrm{atm}\end{array}$ & $\begin{array}{c}\mathrm{P}_{\mathrm{C}_{1}}, \\
\mathrm{~atm}\end{array}$ & $\begin{array}{c}\mathrm{P}_{\mathrm{C}_{2}}, \\
\mathrm{~atm}\end{array}$ & $\begin{array}{c}\mathrm{P}_{\mathrm{C}_{3}}, \\
\mathrm{~atm}\end{array}$ & $\begin{array}{c}\mathrm{P}_{\mathrm{T}}=\text { Total Pressure } \\
\mathrm{atm}\end{array}$ \\
\hline 1900 & $5.68 \times 10^{-6}$ & $3.76 \times 10^{-13}$ & $3.33 \times 10^{-15}$ & $9.57 \times 10^{-15}$ & $5.68 \times 10^{-6}$ \\
2000 & $1.46 \times 10^{-5}$ & $3.82 \times 10^{-12}$ & $5.06 \times 10^{-14}$ & $1.33 \times 10^{-13}$ & $1.46 \times 10^{-5}$ \\
2500 & $5.31 \times 10^{-4}$ & $2.56 \times 10^{-8}$ & $1.57 \times 10^{-9}$ & $2.94 \times 10^{-9}$ & $5.31 \times 10^{-4}$ \\
3000 & $5.81 \times 10^{-3}$ & $9.11 \times 10^{-6}$ & $1.55 \times 10^{-6}$ & $2.31 \times 10^{-6}$ & $5.83 \times 10^{-3}$ \\
3500 & $3.22 \times 10^{-2}$ & $6.05 \times 10^{-4}$ & $2.13 \times 10^{-4}$ & $2.71 \times 10^{-4}$ & $3.32 \times 10^{-2}$ \\
4000 & 0.12 & $1.41 \times 10^{-2}$ & $8.55 \times 10^{-3}$ & $9.64 \times 10^{-3}$ & 0.15 \\
4500 & 0.31 & 0.16 & 0.15 & 0.16 & 0.78 \\
5000 & 0.70 & 1.15 & 1.50 & 1.43 & 4.79 \\
5500 & 1.34 & 5.71 & 9.86 & 8.83 & 25.74 \\
6000 & 2.31 & 21.71 & 47.24 & 40.18 & 111.45 \\
6500 & 3.66 & 67.19 & 177.88 & 144.85 & 393.58 \\
7000 & 5.44 & 176.91 & 554.17 & 434.80 & 1171.3 \\
7500 & 7.65 & 409.42 & 1483.8 & 1127.2 & 3028.0 \\
8000 & 10.33 & 853.15 & 3512.6 & 2594.2 & 6970.2 \\
\hline
\end{tabular}

Frnm the data given in Table 14, the boiling point of $\mathrm{PuC}_{0.88}$ was calculated to be $4564 \mathrm{~K}$.

Thermal Conductivity of Carbide Fuels

Urantum carbide and similar NaCl-type compounds have many metallic characteristics. At high temperatures, heat transfer is mainly electronic and obeys the Wiedmann-Franz law, that is, the thermal conductivity is proportional to the product of temperature and electrical conductivity. At low temperature, a large phonon component will also be present. Lewis and Kerrisk $^{4}$ have recently made a critical evaluation of the low-temperature thermal conductivity of carbide fuels. Their data were extrapolated beyond the melting point, using the approach described below. 
No data on the thermal conductivity of molten carbide fuels are avallable. According to Turnbull, 17 molten salts just above the melting point are generally regarded as having a quasi-crystalline structure, which indicates that heat is transferred mainly by electronic and vibrational mechantsms. Translational or diffusional motion is not important as is evidenced by the high ratio of thermal to mass diffusivity for Iiquids, which varles from about 70 to 100 . For molten salts, the Lorenz ratio (thermal conductivity/electrical conductivity $x \mathrm{~T}$ ) is not constant and is several hundred times the value for metals. Many empirical correlations are avallable in the literature to estimate the thermal conductivity of liquids. Gambill 18 has comptled a few of these correlations; however, the values calculated by these empirical equations differ from the thermal conductivity of solid carbide fuels (in the vicinity of melting point) by a factor of 100 to 1000 . Because of the inadequacy of these equations for application at or near the melting point, an empirical rule proposed by Turnbul1 17 for fused salt was used. According to this rule, the ratio of thermal conductivity of liquid to that of solfd at the melting point is about $0.86 \pm 0.13$. Beyond the melting point, the thermal conductivity of liquids, in general, show varied behavior. Often it elther increases first and then levels off or it decreases continuously. In the case of carbide fuels, the behavior of thermal conductivity above melting is difficult to predict. In the absence of spectific information, a constant value is recommended for liquid thermal conductivity. The low-temperature data for $100 \%$ theoretically dense $\mathrm{UC}, \mathrm{PuC}$, and $\left(\mathrm{U}_{0.8} \mathrm{Pu} 0.2\right) \mathrm{C}$ were calculated from the equations given by Lewis and Kerrisk ${ }^{4}$. These are given in Tables 15-17. These data and the empirical approach mentioned above was used to calculate values for the liquid thermal conductivity; these are given in Table 18 .

Viscosity of Carbide Fuels

Viscosity data for molten fuel materials are very scarce. Tsai and 0lander ${ }^{19}$ reported the viscosity of $\mathrm{UO}_{2}$ at the melting point to be $8 \pm 1$ centipolse. Using several empirical rules and corresponding-state and Eyring-type calculations, Chasanov 20 recommended a mean value of about 5 centipoise at the melting point of mixed-carbide fuel. Bird, Stewart, and Lightfoot ${ }^{21}$ presented the following empirical equation for the viscosity of liquids:

$$
\mu \sim \frac{N h}{V} \exp \left(3.8 T_{b} / T\right)
$$

where $\mu=$ viscosity, poise $[\mathrm{g} /(\mathrm{cm})(\mathrm{sec})]$

$$
\begin{aligned}
\mathrm{N} & =\text { Avogadro's number, }\left(6.023 \times 10^{2.3} \text { molecules } / \mathrm{mol}\right) \\
\mathrm{V} & =\text { Molar volume at temperature } \mathrm{T},(\mathrm{cc} / \mathrm{mol}) \\
\mathrm{T}_{\mathrm{b}} & =\text { normal boiling point, }(\mathrm{K}) \\
\mathrm{T} & =\text { temperature, }(\mathrm{K}) \\
\mathrm{h} & =\text { Planck's constant, }\left(6.624 \times 10^{-27} \mathrm{erg}-\mathrm{sec} \text { or } \mathrm{g} \cdot \mathrm{cm}^{2} / \mathrm{sec}\right)
\end{aligned}
$$

Andradae's $\mathrm{s}^{22}$ equation, based on the quasi-crystalline structure of 1iquids, states that at the melting point:

$$
\mu=5.1 \times 10^{-4}\left(\mathrm{MT}_{\mathrm{m}}\right)^{1 / 2} / \mathrm{v}_{\mathrm{m}}^{2 / 3}
$$


TABLE 15. Thermal Conductivity of $100 \%$ Theoretically Dense UC

\begin{tabular}{rccc}
\hline $\begin{array}{r}\text { Temp, } \\
{ }^{\circ} \mathrm{C}\end{array}$ & $\begin{array}{c}\mathrm{k} \\
\mathrm{cal} /(\mathrm{sec})(\mathrm{cm})\left({ }^{\circ} \mathrm{C}\right)\end{array} \bar{c}^{{ }^{\circ} \mathrm{C}}, \begin{array}{c}\mathrm{k} \\
\mathrm{cal} /(\mathrm{sec})(\mathrm{cm})\left({ }^{\circ} \mathrm{C}\right)\end{array}$ \\
\hline 300 & 0.0505 & 1500 & 0.0536 \\
400 & 0.0503 & 1600 & 0.0539 \\
500 & 0.0504 & 1700 & 0.0543 \\
600 & 0.0506 & 1800 & 0.0547 \\
700 & 0.0510 & 1900 & 0.0550 \\
800 & 0.0511 & 2000 & 0.0554 \\
900 & 0.0515 & 2100 & 0.0557 \\
1000 & 0.0518 & 2200 & 0.0561 \\
1100 & 0.0522 & 2300 & 0.0564 \\
1200 & 0.0525 & $2400^{\mathrm{b}}$ & 0.0568 \\
1300 & 0.0529 & $2507^{\mathrm{b}}$ & 0.0572 \\
1400 & 0.0532 & & \\
\hline
\end{tabular}

$\mathrm{a}_{\text {Recommended by Lewis et. } a l^{4}}$

$\mathrm{b}_{\text {Extrapolation based on: }}$

$$
\begin{array}{ll}
k=0.0519-7.266 \times 10^{-6} \mathrm{~T}+8.628 \times 10^{-9} \mathrm{~T}^{2} ; & 50<\mathrm{T}^{\circ} \mathrm{C}<700 \\
\mathrm{k}=0.0483+3.537 \times 10^{-6} \mathrm{~T} & ; 700<\mathrm{T}^{\circ} \mathrm{C} \leqslant 2300
\end{array}
$$

TABLE 16. Thermal Conductivity of $100 \%$ Theoretically Dense PuC. ${ }^{a}$

\begin{tabular}{cccc}
$\begin{array}{c}\text { Temp, } \\
{ }^{\circ} \mathrm{C}\end{array}$ & $\begin{array}{c}\mathrm{k}, \\
\mathrm{cal} /(\mathrm{sec})(\mathrm{cm})\left({ }^{\circ} \mathrm{C}\right)\end{array}$ & $\begin{array}{c}\text { Temp, } \\
{ }^{\circ} \mathrm{C}\end{array}$ & $\begin{array}{c}\mathrm{k}, \\
\mathrm{cal} /(\mathrm{sec})(\mathrm{cm})\left({ }^{\circ} \mathrm{C}\right)\end{array}$ \\
\hline 300 & 0.0175 & 1000 & 0.0368 \\
400 & 0.0185 & 1100 & 0.0419 \\
500 & 0.0201 & 1200 & 0.0475 \\
600 & 0.02 .23 & 1300 & 0.0537 \\
700 & 0.0251 & $1400^{\mathrm{b}}$ & 0.0605 \\
800 & 0.0284 & $1500^{\mathrm{b}}$ & 0.0679 \\
900 & 0.0323 & $1602^{\mathrm{b}}$ & 0.0759
\end{tabular}

$a_{\text {Recommended by Lewis et } a Z^{4}}$

$b_{\text {Txtrapolation baced on: }}$

$$
\mathrm{k}=0.0178-9.656 \times 10^{-6} \mathrm{~T}+2.868 \times 10^{-8} \mathrm{~T}^{2} \quad ; \quad 100 \leq \mathrm{T}^{\circ} \mathrm{C} \leq 1300
$$


TABLE 17. Thermal Conductivity of $100 \%$ Theoretically Dense $\left(\mathrm{U}_{0.8} \mathrm{Pu}_{0.2}\right) \mathrm{C}$.

\begin{tabular}{cccc}
\hline $\begin{array}{c}\text { Temp, } \\
{ }^{\circ} \mathrm{C}\end{array}$ & $\begin{array}{c}\mathrm{k}, \\
\mathrm{cal} /(\mathrm{sec})(\mathrm{cm})\left({ }^{\circ} \mathrm{C}\right)\end{array}$ & $\begin{array}{c}\text { Temp, } \\
{ }^{\circ} \mathrm{C}\end{array}$ & $\begin{array}{c}\mathrm{k}, \\
\mathrm{cal} /(\mathrm{sec})(\mathrm{cm})\left({ }^{\circ} \mathrm{C}\right)\end{array}$ \\
\hline 300 & 0.0395 & 1500 & 0.0516 \\
400 & 0.0395 & 1600 & 0.0523 \\
500 & 0.0399 & 1700 & 0.0529 \\
600 & 0.0414 & 1800 & 0.0534 \\
700 & 0.0429 & 1900 & 0.0538 \\
800 & 0.0443 & 2000 & 0.0542 \\
900 & 0.0456 & 2100 & 0.0544 \\
1000 & 0.0468 & 22.00 & 0.0545 \\
1100 & 0.0480 & 2300 & 0.0545 \\
1200 & 0.0490 & $2400^{\mathrm{b}}$ & 0.0545 \\
1300 & 0.0500 & $2485^{\mathrm{b}}$ & 0.0545 \\
1400 & 0.0508 & & \\
\hline
\end{tabular}

Recommended by Lewis et al. 4

bxtrapolation based on:

$$
\begin{aligned}
& k=0.0418-1.3504 \times 10^{-5} \mathrm{~T}+1.946 \times 10^{-8} \mathrm{~T}^{2} ; \quad 50 \leq \mathrm{T}^{\circ} \mathrm{C} \leq 500 \\
& k=0.0305+2.082 \times 10^{-5} \mathrm{~T}-4.493 \times 10^{-9} \mathrm{~T}^{2} ; 500 \leq \mathrm{T}^{\circ} \mathrm{C} \leq 2300
\end{aligned}
$$

TABLE 18. Thermal Conductivity of Carbide Fuels In the Liquid Kegion. (100\% T.D.)

\begin{tabular}{ccc}
\hline Compound & $\begin{array}{c}\mathrm{k}_{\mathrm{s}} \odot \mathrm{T}_{\mathrm{m}} \\
\mathrm{cal} /(\mathrm{sec})(\mathrm{cm})\left({ }^{\circ} \mathrm{C}\right)\end{array}$ & $\begin{array}{c}\mathrm{k}_{\ell} @ \mathrm{~T}_{\mathrm{m}} \\
\mathrm{cal} /(\mathrm{sec})(\mathrm{cm})\left({ }^{\circ} \mathrm{C}\right)\end{array}$ \\
\hline $\mathrm{UC}$ & 0.0572 & 0.049 \\
$\mathrm{PuC}$ & 0.0759 & 0.065 \\
$\left(\mathrm{U}_{0.8} \mathrm{Pu}_{0.2}\right) \mathrm{C}$ & 0.0545 & 0.047
\end{tabular}

an this table, $k_{s}$ represents the thermal conductivity of the solid state; $k_{\ell}$ represents the thermal conductivity of the liquid state; and $\mathrm{T}_{\mathrm{m}}$ represents the melting point. 
where $M=$ molecular weight

$$
\begin{aligned}
& \mathrm{T}_{\mathrm{m}}=\text { melting point, }(\mathrm{K}) \\
& \mathrm{V}_{\mathrm{m}}=\text { molar volume; (cc/mol) }
\end{aligned}
$$

Usually viscosity is related to the inverse of temperature by a logarithmic relation; however, in the present case, the use of a constant is recommended for the liquid region until more experimental data are available. By means of Eqs. 43 and 44 and other necessary data from this report, viscosity values were calculated at the melting point. These are listed in Table 19, along with the recommended values.

TABLE 19. Viscosity of Carbide Fuels

\begin{tabular}{cccc}
\hline Compound & $\begin{array}{c}\mu_{\mathrm{m}} \\
\text { (centipoise) } \\
\text { Calcd. from Eq. 43 }\end{array}$ & $\begin{array}{c}\mu_{\mathrm{m}} \\
\text { (centipoise) } \\
\text { Calcd. from Eq. } 44\end{array}$ & $\begin{array}{c}\mu_{\mathrm{m}} \\
\text { (centipoise) } \\
\text { Recommended }\end{array}$ \\
\hline $\mathrm{UC}$ & 11.3 & 4.9 & 8 \\
$\left(\mathrm{U}_{0.8} \mathrm{Pu}_{0.2}\right) \mathrm{C}$ & 8.3 & 4.9 & 7 \\
$\mathrm{PuC}_{0.88}$ & 169.6 & 4.1 & 4 \\
\hline
\end{tabular}

The value of viscosity for $\mathrm{PuC}_{0.88}$, calculated from Eq. 43, is unreasonably high. This may be due to the lower melting point of $\mathrm{PuC} 0.88$ in comparison with those of other carbides. Therefore, the use of this particular value is not recommended.

\section{Emissivity of Carbide Fuels}

In analyzing the interchange of radiant energy among various components of a reactor, their emission, reflection, and absorption characteristics must be known. In specifying the radiation properties, various degrees of detail are required, depending upon the nature of the application. For instance, the calculation of the radiant energy emitted into the entire hemispherical space above a surface element requires knowledge of the hemispherical emittance. Furthermore, depending on whether the calculation is to be performed over all wavelengths or in a specific wavelength range, either the total or the spectral (monochromatic) emittance is correspondingly required. The magnitude, the angular distribution, and the wavelength dependence of the radiation properties are all very sensitive to the condition of the surface. Surface condition includes such factors as roughness, oxide layers, and physical and chemical contamination. In the case of dielectric materials, the grain structure of the material may also affect the radiation properties. The qualitative description of a surface by terms such as smooth, polished, rough, and oxidized is generally insufficient to permit an accurate specification of the radiation properties. 
Emissivity measurements on UC have been made by Grossman ${ }^{23}$, and DeConinck ${ }^{24}$. Grossman measured the normal spectral $\left(\varepsilon_{0.65 \mu \mathrm{m}}\right)$ as well as total normal emissivity $\left(\varepsilon_{t}\right)$ of UC, whereas DeConinck ${ }^{24}$ measured only the normal spectral emissivity. To evaluate the reliability of Grossman and DeConinck's data, we compare their data with the experimental data available on refractory carbides such as niobium, hafnium, tantalum, titanium, tungsten, vanadium, and zirconium. The data for total normal emittance for refractory carbides were taken from a report prepared by Southern Research Institute. 25 The data for normal spectral emittance $(0.65 \mu \mathrm{m})$ for refractory carbides were taken from the compilation of Touloukian and DeWitt. ${ }^{26}$ In Fig. 2, total normal emissivity is presented as a function of temperature.

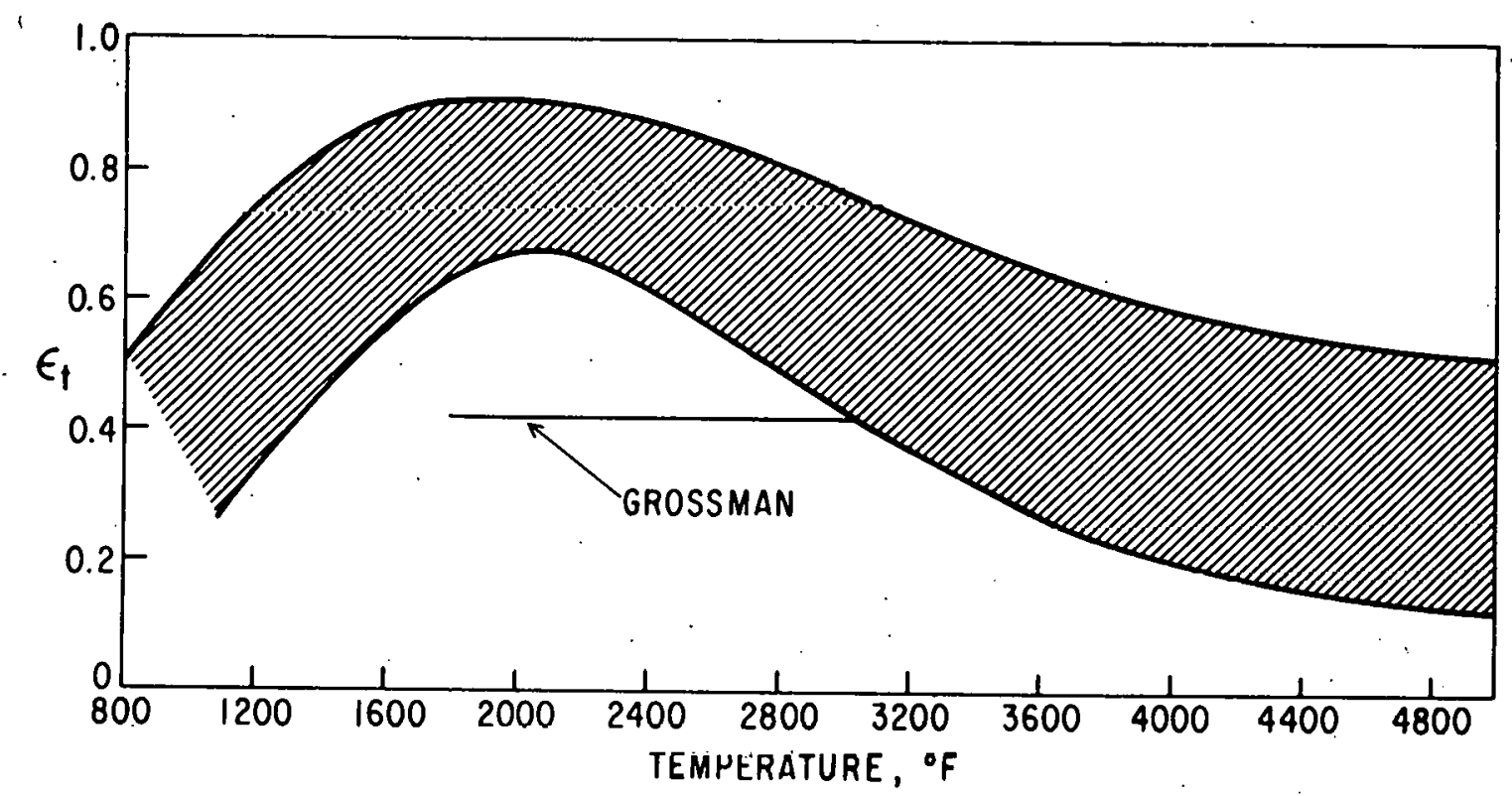

Fig. 2. Total Normal Emittance of Refractory Carbides.

In Fig. 3, normal spectral emissivity is presented as a function of temperature. The total as well as spectral emissivity data for refractory carbides fell within a narrow bands and therefore, in Figs. 2 and 3 orily the band is shown. The equations representing the mean value are (using the respective units given in Ref. 25 and 26):

$$
\begin{gathered}
\varepsilon_{t}=-0.6403+1.5906 \times 10^{-3} \mathrm{t}-5.5607 \times 10^{-7} \mathrm{t}^{2}+5.5741 \times 10^{-11} \mathrm{t}^{3} \\
800^{\circ} \mathrm{F}<\mathrm{t}<4800^{\circ} \mathrm{F} ; \text { Average error }= \pm 40 \% \\
=0.5209+3.737 \times 10^{-4} \mathrm{~T}-1.6747 \times 10^{-7} \mathrm{~T}^{2}+1.6901 \times 10^{-11} \mathrm{~T}^{3} \\
\begin{aligned}
1000 \mathrm{~K}<\mathrm{T}<4200 \mathrm{~K} ; \text { Average error }= \pm 21 \%
\end{aligned}
\end{gathered}
$$




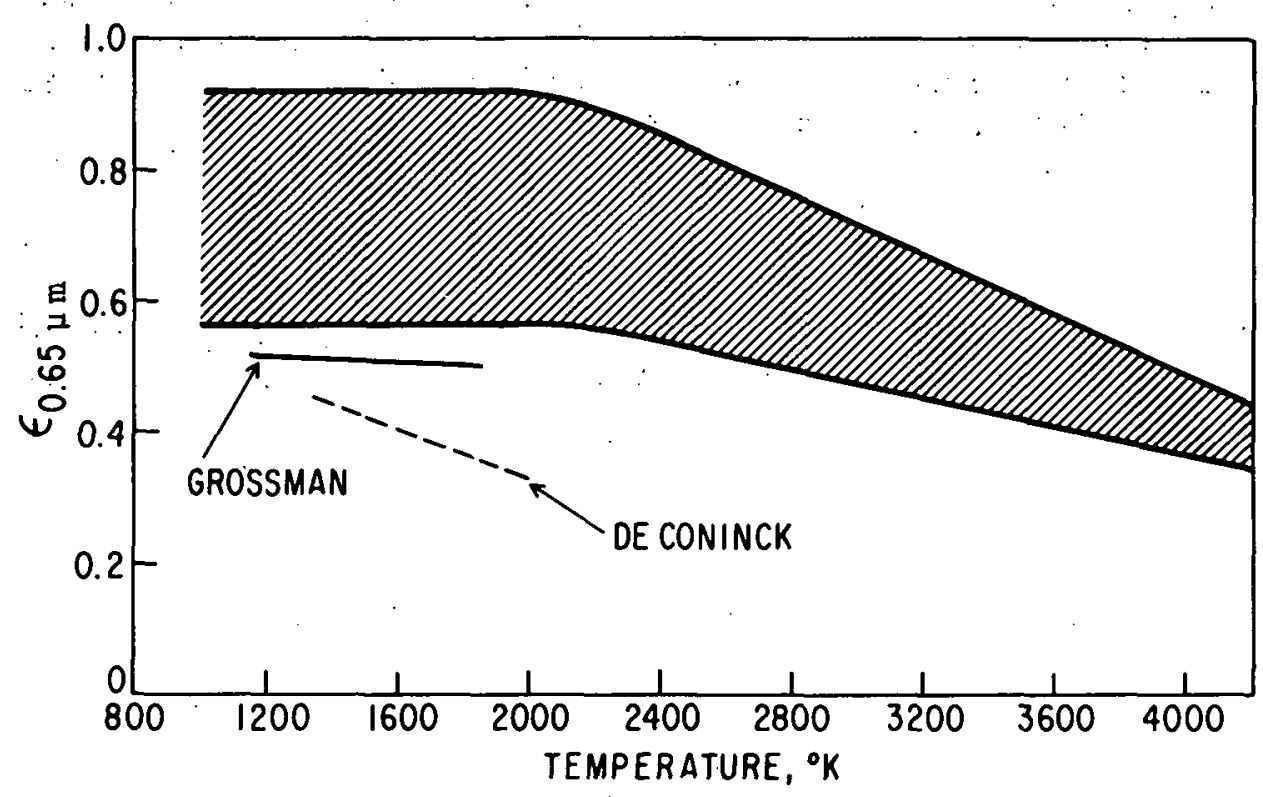

Fig. 3. Normal Spectral Emittance of Refractory Carbides.

Grossman' $s^{23}$ and DeConinck's $s^{24}$ data are also shown in Figs. 2 and 3. Their values are lower than the lower limits given by Eqs. 45 and 46 . Unreported measurements by D. Stahl 27 of the total emissivity of UC also indicated that higher values (about 0.8 ) were correct. In considering these uncertainties we tentatively recommend for $\mathrm{UC}, \mathrm{PuC}_{0.88}$, and $\left(\mathrm{U}_{0.8} \mathrm{Pu}_{0.2}\right) \mathrm{C}$, the emissivity values measured on UC by Grossman. It should be borne in mind, however, that these emissivity values may be too low. The recommended values are as follows:

$$
\begin{aligned}
& \varepsilon_{t}=0.42 \pm 0.02 ; \quad 1250 \mathrm{~K}<\mathrm{T}<1980 \mathrm{~K} \\
& \varepsilon_{0.65 \mathrm{~mm}}=0.539-2 \times 10^{-5} \mathrm{~T} ; \quad 1150 \mathrm{~K}<\mathrm{T}<1890 \mathrm{~K}
\end{aligned}
$$

\section{Conclusions}

This report presents a recommended set of various thermophysical and transport property values for candidate advanced carbide fuels, which may reasonably be used until more experimental or theoretical data are available. Whenever possible, standard estimation precedures were used to estimate the values. In some cases, analogy with compounds of better known behavior was used to estimate the necessary values. In some cases, the estimated data were fitted to standard equations with little or no attempt made to optimize the form of equations. In making estimates of various property values, attempts were made to preserve internal consistency as well as consistency with other properties and also with the low-temperature data (that is, data 
below the melting point). Even then, care should be exercised in using these data. This work has revealed a significant gap in the information for carbides in the 1iquid region. Both experimental work and additional analyses are needed to rectify this situation.

\section{ACKNOWLEDGMENTS}

The authors wish to express their appreciation to Drs. R. Ackermann, P. Blackburn, M. Tetenbaum, and G. Winslow for helpful suggestions and discussions. 
REFERENCES

1. M. Tetenbaum et al., A Review of the Thermodynamics of the U-C, Pu-C and U-Pu-C Systems. ANL -AFP-8 (June 1975)

2. D. Fee and C.E. Johnson, Phase Equilibria and Melting Point Data for Advanced Fuel Systems, ANL-AFP-10 (June 1975).

3. J.F. Andrew, Review of Thermal Expansion and Density of Uranium and Plutonium Carbides, Los Alamos Scientific Laboratory report (to be published).

"4. H.D. Lewis et al., A Review of the Literature on the Electrical and Thermal Transport Properties of the Carbides of Uranium and Plutonium, Los Alamos Scientific Laboratory report (to be published).

5. H.K. Richards, Thermal Expansion of Urantum and Tantalum Monocarbides up to $2700^{\circ} \mathrm{C}$, Nucl. Technol. 10, 54 (1971)

6. A.D. Kirshenbaum et al., The Density of Liquid NaC1 and $\mathrm{KCl}$ and an Estimate of Their Critical Constants together with those of other Alkali Halides, J. Inorg. Nucl. Chem. 24, 1287 (1962)

7. G.J. Janz, Molten Salts Handbook, Academic Press, New York, (1967)

8. R.J. Ackermann, P. Potter, M. Rand, and E.K. Storms, IAEA Pane1 Assessment of the Thermodynamic Properties of the $\mathrm{U}-\mathrm{C}, \mathrm{Pu}-\mathrm{C}$, and $\mathrm{U}-\mathrm{Pu}-\mathrm{C}$ Systems, Grenoble, France; May 6-8, 1974, (to be pub1ished).

9. G.H. Winslow, Argonne National Laboratory, private communication (1975).

10. G.H. Winslow, Thermomechanical Properties of Real Materials: The Thermal Expansions of $\mathrm{UO}_{2}$ and $\mathrm{ThO}_{2}$, High Temp. Sci. 3,361 (1971).

11. A. Sheth and L. Leibowitz, Equation-of-State for Advanced Fuels: Interim Report, ANL-AFP-2 (October 1974).

12. 0.H. Hougen, K.M. Watson, and R.A. Ragatz, Chemical Process Principles, Part II, Thermodynamics 2nd ed., p. 569-576, John Wiley and Sons, Inc., New York (1959).

13. D. Miller, "A Critical Review of the Properties of Materials at High Temperatures and Pressures Significant for Fast Reactor Safety", Proc. of the Conf. on Safety, Fuels, and Core Design in Large Fast Reactors, Oct. 11-14, 1965, ANL-7120, p.641-653 (1966).

14. P. Blackburn, Argonne National Laboratory, private communication, (1975).

15. P.E. Potter and W.G. Roberts, UKAEA Report AERE-R-5661 (1968).

16. P.E. Potter, UKAEA Report AERE-R-5922 (1968). 
17. A.G. Turnbul1, The Thermal Conductivity of Molten Salts, II: Theory and Results for Pure Salts, Aust. J. Applied, Sc1. 12, 324 (1961).

18. W.R. Gambill, Predict Thermal Conductivity I, II, Chem. Engr., p. 237240, (February 1957), and p. 271-276, (March 1957).

19. H.C. Tsai and D.R. Olander, Trans, Am. Nucl. Soc. 15, 211 (1972).

20. M.G. Chasanov, Argonne National Laboratory, private communication (1974).

21. R.B. Bird, W.E. Stewart, and E.N. Lightfoot, Transport. Phenomena, p. 26-29, John Wiley and Sons, Inc., New York (1960).

22. J.R. Partington, An Advanced Treatise on Physical Chemistry, Vol. 2, The Properties of Liquids, p. 108, Longmans, Green and Company, New York, Toronto (1951).

23. L.N. Grossman, High-'lemperature Thermophysical Properties of Uranium Monocarbide. J. Am. Ceram. Soc: 46, 264 (1963).

24. R. DeConinck, Physical Properties of Uranium Carbides, Annual Scientific Report, 1973, BLG 495/74, ed. R. Billiau, K. Bobin, G. Michiels, and J. Proost.

25. Thermal Properties of Twenty-Six Solid Materials to $5000^{\circ} \mathrm{F}$ or Their Destruction Temperature, Southern Research Institute, Birmingham, Alabama, ASD-TDR-62-765, August (1962).

26. Y.D. Touloukian and D.P. DeWitt, Thermophysical Properties of Matter, Vo1. 8: Thermal Radiative Properties-Nonmetallic Solids, IFI/P1enum, New York, (1972).

27. D. Stahl, Argonne National Laboratory, private communication (1975). 